\title{
Spatio-temporal variability of fog-water collection in the eastern Iberian Peninsula: 2003-2012
}

\author{
Maria J. Estrela $^{\mathrm{a}, *}$, David Corell ${ }^{\mathrm{a}}$, Jose A. Valiente ${ }^{\mathrm{b}}$, Cesar Azorin-Molina ${ }^{\mathrm{c}, \mathrm{d}}$, Deliang Chen $^{\mathrm{c}}$ \\ ${ }^{a}$ Departamento de Geografía, Universitat de Valencia, Avda. Blasco Ibáñez 28, 46010, Valencia, Spain \\ ${ }^{\mathrm{b}}$ Fundación CEAM (Fundación Centro de Estudios Ambientales del Mediterráneo), Parque Tecnológico, Calle Charles R. Darwin 14, 46980 Paterna, Valencia, Spain \\ ${ }^{\mathrm{c}}$ Regional Climate Group, Department of Earth Sciences, University of Gothenburg, Sweden \\ ${ }^{\mathrm{d}}$ Centro de Investigaciones sobre Desertificación, Consejo Superior de Investigaciones Científicas (CIDE-CSIC), Montcada, Valencia 46113, Spain
}

\section{A R T I C L E I N F O}

\section{Keywords:}

Fog-water collection

Variability

Eastern Iberian Peninsula

\begin{abstract}
A B S T R A C T
Among the different inputs involved in the hydrological system, fog water measured by man-made passive devices is one of the most unknown components, although it could be an additional water resource for specific environmental applications (forest restoration, forest firefighting, etc.). Focusing on the Mediterranean Iberian Peninsula, the aim of this work is to quantify fog-water collected by a 24-fog-stations network spread across three latitudinal sectors with different locations (coastal, pre-littoral and inland), and to determine the most productive sites. Measurements from the network show that distance-to-sea, latitude or elevation differences between stations are factors affecting fog-water collection potential. The network, based on passive cylindrical omnidirectional fog-water collectors, was active during the period 2003-2012. In addition to fog collection, other environmental variables such as rainfall, wind speed and wind direction, air temperature and relative humidity were measured. These ancillary data were used in a specific data reduction technique to eliminate the simultaneous rainwater component from the fog water measurements, and in the retrieval of the optimum mean wind directions to harvest fog-water efficiently. It was concluded that (i) positive differences in elevation allow greater collection rates, even under $100 \mathrm{~m}$ differences; (ii) optimum harvesting wind directions for inland locations are in line with the orientation of the existent valley coupled with the shortest path to the coastline, their collected fog-water volumes being generally smaller than those near the coast; (iii) fog-water collection at coastal locations present more dispersed optimal wind directions, ranging from north to the direction of the most immediate coastline; and (iv) there is a practically null dependence of the optimum mean wind direction on seasonality, but a strong dependence of fog-water captured volumes, however.
\end{abstract}

\section{Introduction}

The Mediterranean Iberian Peninsula, characterised by dry hot summers followed by wet mild winters, presents major water resources problems (Instituto Tecnológico y Geominero de España y Consellería de Agricultura y Medio Ambiente, 1996; Gil Olcina and Rico, 2007; Garcia-Ruiz et al., 2011). The region features irregular torrential precipitations and marked summer dryness, which results in increasingly serious water supply/availability issues (Gallart and Llorens, 2002; De Luis et al., 2010; Estrela et al., 2012). In Spain, more than half the years between 1980 and 2000 were classified as dry or very dry (Estrela et al., 2000; Pérez Cueva, 2001; De Castro et al., 2005, Cuadrat and Martin Vide, 2007). According to the Spanish Ministry of Environment data, 7 years of the 1980s were considered dry or very dry, as were 5 years of the 1990s (Ministerio de Medio Ambiente, 1998; Ministerio de Medio
Ambiente, 2000a,b). Now in the 21st century, Spain is suffering longer and more intense droughts (Vicente-Serrano et al., 2014); 2011-2012 has been revealed as one of the driest in the last 200 years (Tejedor et al., 2016, 2017). These climate traits have made the natural water resource to be considered a good to be protected and taken care of, and programmes that ensure knowledge and the follow-up of water resources in all their facets are needed.

To evaluate the water resources of a region, it is necessary to know the importance of all the inputs in the hydrologic system, which depend on the climate characteristics in each region. Former studies conducted in the western Mediterranean Basin (Millán et al., 1998, 2005a,b; Estrela et al., 2000; Miró et al., 2017) reveal that the main inputs in the hydrologic system are precipitation caused by disturbances that occur as Atlantic fronts, cyclogeneses in the Mediterranean, summer convective systems as well as fog or dew. Although many studies on

\footnotetext{
* Corresponding author.

E-mail address: majoesna@uv.es (M.J. Estrela).
} 
precipitation have been conducted, few comprehensive studies have appeared in the scientific literature about fog-water collection in the Mediterranean Iberian Peninsula (Millán et al., 1998; Estrela et al., 2008; Valiente et al., 2011: Corell et al., 2011; Klemm et al., 2012).

The limited existing studies have pointed out that in certain mountainous regions on the coast, fog-water collection indices exceed the direct precipitation indices by $2-3$-fold. This finding indicates fogwater collection is potentially an important water resource for these regions. Although the summer fog-water rate is low, it tends to generally exceed precipitation (Estrela et al., 2009), which is a fundamental fact, given that the Mediterranean climate is characterised by severe lack of precipitations in summer (Estrela et al., 2008).

Based on interest in acquiring knowledge about fog water along the Mediterranean Iberian Peninsula, this work focuses on quantifying the volumes collected in different coastal and inland sectors. Achieving this goal would help determine which areas are more productive at collecting fog-water, which in turn would facilate identifying any latitudinal and elevation gradient, as well as dependence on distance from the sea for fog-water collection.

\section{Geographic and climatic setting}

Fig. 1 shows the Iberian Mediterranean area, which is characterised by the presence of coastal mountain ranges that co-exist with large coastal plains where the main rivers including the Ebro, Turia, Júcar, and Segura in this area flow into. This region depicts sharp geographic contrasts: large coastal plains in the centre, mainly in the provinces of Valencia and Castellón, along with other narrower ones to the north and south, which may end in deltas that are not that significant -except for the Ebro Delta-, being surrounded by rocky reliefs and cliffs that often exceed elevations of $500 \mathrm{~m}$ and are close to the coast. This region's western part is limited by main mountain systems, such as the Bética mountain range to the south, the Ibérico mountain range in the centre, and the Catalan Coastal mountain range and the Pyrenees to the north (Fig. 1). The study area is limited by the Mediterranean Sea to the east and covers some $60 \mathrm{~km}$ towards the inland area of the Iberian Peninsula. It has a complex orography, with a coastline that is $>1700 \mathrm{~km}$ long with a SW-NE orientation.

The climate in this area is typically Mediterranean. Air temperatures are generally mild, and average annual values are between $15^{\circ} \mathrm{C}$ in some sectors on the Catalan coast and $18{ }^{\circ} \mathrm{C}$ on the Almerian coast (Martin-Vide and Olcina-Cantos, 2001), with a positive north to south gradient, and from inland to the coast. The average annual precipitation can exceed $800 \mathrm{~mm}$ in the Pyrenees and the mountain area that runs between the provinces of Alicante and Valencia, and can go below $300 \mathrm{~mm}$ in the SE (Capel-Molina, 2000), while the area surrounding Cape Gata (south of Almería) stands out for its extreme aridity, with values between $125 \mathrm{~mm}$ and $150 \mathrm{~mm}$. This is the driest place in continental Europe (Martin-Vide and Olcina-Cantos, 2001). Some of the characteristics of the precipitation in this area stand out, such as its torrentiality, which is more marked in areas near the coast, its irregularity and long dry periods, particularly in summer and in the southern part.

As regards this region's potential for fog-water collection, according to Schemenauer and Cereceda (1994) several geographic conditions favour frequent occurrence of fog in mountainous areas. The fact that mountain ranges are close to the coastland, whose elevation exceeds $500 \mathrm{~m}$, ensures that humid winds from the Mediterranean sea produce clouds when sweeping over the land (Azorin-Molina et al., 2009), which results in fog formation when they hit the land. Collection of water from such fog can be easily done with passive systems, known as fog collectors, which require wind being present so that the water droplets that form fog can be effectively deposited (Estrela et al., 2009).

In a changing climate, precipitation studies for the Mediterranean fringe of the Iberian Peninsula suggest a general decline in precipitation (Quereda Sala et al., 1999; Millán et al., 2005b; Martin Vide and López-
Bustins, 2006; Miró et al., 2016). Climate simulations also confirm this pattern and project a generalised reduction in precipitation for the $21^{\text {at }}$ century (De Castro et al., 2005). For example, the general precipitation tendency in the central sector of the eastern slope in the Iberian Peninsula is negative, especially for small precipitation volumes $(<30 \mathrm{~mm}$ /event), which are generally related with Atlantic fronts and summer convective systems, and are geographically associated with inland mountainous areas, i.e., recharge areas of the hydrologic system (Millán et al., 2005a,b; Miró et al., 2017).

\section{Data and methods}

Although existing fog-water collection technology is simple, there are no well-accepted instruments to collect and quantify fog. Among the passive devices available, the cylindrical collector described in Falconer and Falconer (1980) was chosen as the basis to build the collectors employed in this study for prospecting the fog-water collection potential. A description of the handmade cylindrical collector that was used extensively in the present study can be seen in Estrela et al. (2008). A singular configuration to meet the demands of an assay applied to forestry restoration was also taken (Estrela et al., 2009): a flat industrial collector, i.e. a large fog-water collector (Schemenauer and Cereceda, 1994), as well as a cylindrical prospecting collector, were used in just one of the locations. The large fog collector, LFC, is an element that does not tend to be used for research because, apart from collecting water in large volumes that are not easy to measure with conventional rain gauges, its collection efficiency diminishes when the wind blows in parallel with the flat surface of the collector. Thus, if one of our aims is to analyse the most favourable direction for harvesting fog-water at all the locations, this type of collector will not be useful obviously. The consideration of the advantages and disadvantages of using this type of collector, i.e. flat collectors versus cylindrical ones, was done in works by Juvik and Nullet (1995) and Schemenauer et al. (1995). Using cylindrical collectors to set up a network for prospecting the fog-water collection potential was motivated because they act as omnidirectional devices; that is, they work independently of orientation and, hence, their exposure to wind from any direction is uniform. This allows fundamental information to be acquired about the predominant directions of fog-water at each location. This is most interesting for future applications where orientating LFCs is necessary to efficiently harvest large fog-water volumes.

On top of each cylindrical collector, a $60 \mathrm{~cm}$-diameter plastic tray was placed to avoid any interference by rain as much as possible, as recommended in Juvik and Nullet (1995). In this way, any intercepted rainwater is diverted from the collector and measured independently. This configuration was done to basically reproduce the performance of a flat collector, such as an LFC which is the ultimate objective of any prospecting study, but maintaining omnidirectional properties. In fact, a cylindrical collector is actually a tridimensional object as opposed to a bidimensional one represented by the flat collector. Evidently, completely avoiding any rainwater interfering with the water volumes collected by the cylindrical collector is impossible. The faster the wind blows, the more the rainwater droplets transported by it will enter the fog collector. Schemenauer and Cereceda, (1994) and Schemenauer et al. (1995) previously indicated that when fog and precipitation simultaneously occur, separation of one from another is difficult, especially when passive-type instruments are used. Their study included many events that contained only fog, such as fog combined with precipitation, which can take place at various intensities or before/during/ after fog occurrence. Concurrent precipitation measurements taken by an independent rain gauge can often provide information to be compared with the fog-water volume measurements taken by a cylindrical collector. In some studies, the collected fog volumes have been refined to minimise pollution effects caused by rain with correction coefficients or other data filtering processes (Juvik and Nullet, 1995; Olivier and De Rautenbach, 2002). 


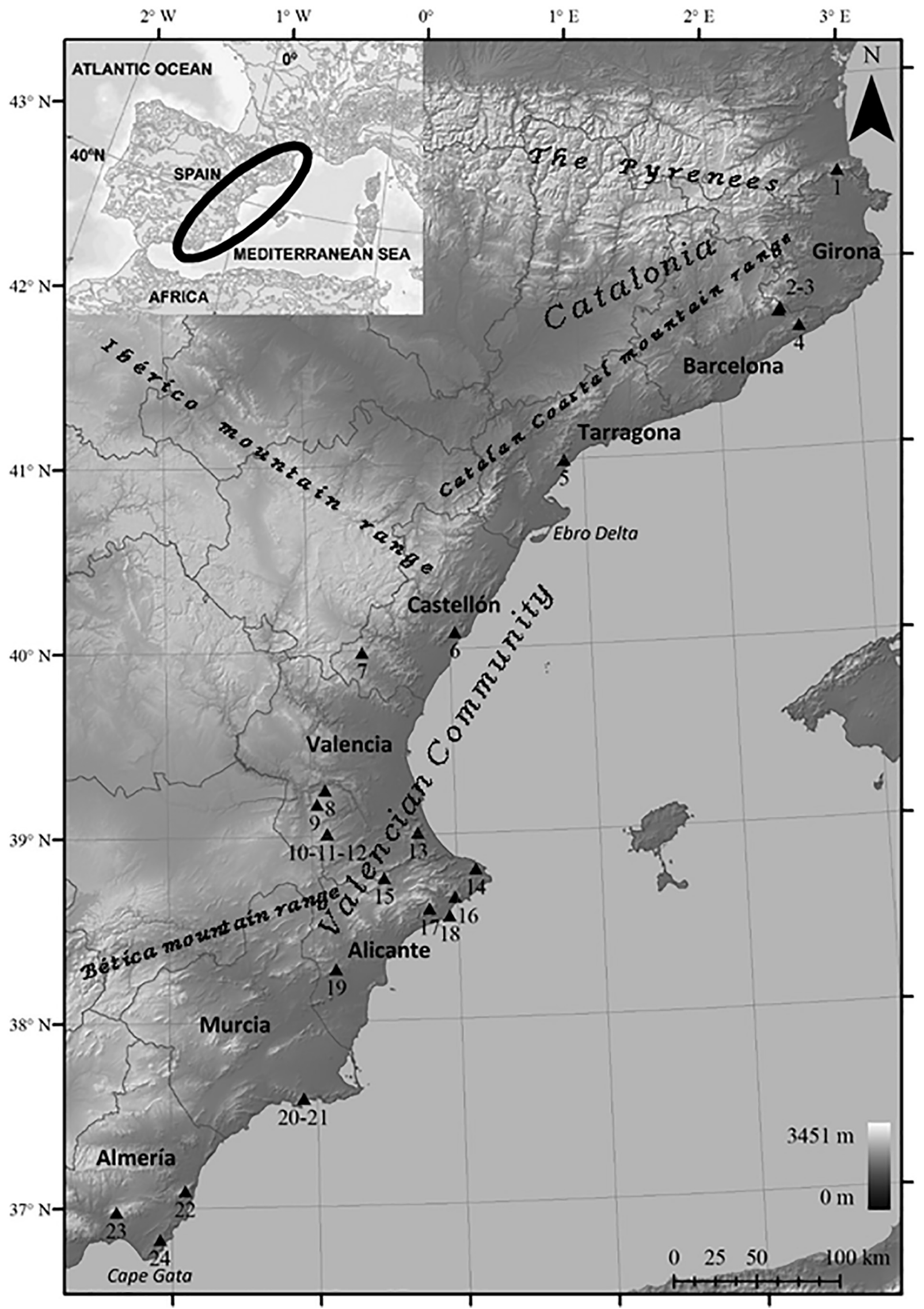

Fig. 1. Study area located in the East of the Iberian Peninsula. Solid triangles and figures indicate the geographical position of stations and their respective code numbers. 
In the present study, the variable 'fog' represents water volume per square metre of effective collection surface per day collected by a fog collector, which could be fog, precipitation, or a mixture of both. To calculate the variable 'pure fog', with the same units, a filtering was used that eliminates contributions from rain. The correction depends on wind speed and rain, apart from fog (Estrela et al., 2008). Finally, the variable 'rain' corresponds to the precipitation values, in $\mathrm{mm}$ per day, that includes the rainfall recorded by the rain gauges set up at each location. The filtering technique is based on the parameterisation that is specific of the cylinder collector and upper plastic tray combination presented herein. This methodology can be exported to other similar configurations, but its use is not recommended unless the taken configuration is identical.

For each network's station, the cylindrical collector is assembled at the highest point of a 3 metre-high galvanised steel mast. This mast stands erect and is held straight to the ground by three stays. To this mast, a series of instruments is also attached at several heights: a vaneanemometer manufactured by Davis Instruments (Model 7914) at $3 \mathrm{~m}$; two tipping bucket rain gauges, also produced by Davis Instruments (Model $7856 \mathrm{M}, 0.2 \mathrm{~mm}$ resolution; one to measure direct precipitation and the other two measure fog-water volumes), four wetness sensors made by Campbell Scientific Inc. (Model 237F) and, finally, a temperature/relative humidity probe produced by Vaisala (Model 50Y) at $2 \mathrm{~m}$. Automatic data acquisition was done with a Campbell CR510 datalogger. Data were transmitted by a GSM modem once a day. The sampling done with sensors was carried out at 6-second intervals to generate instantaneous and/or accumulated data, which were later included in 10-minute statistics, whose results were stored in the datalogger.

Network design (placing stations, network size or density) was based upon the geographic and climate characteristics of the area. The resulting network covered a length of $1700 \mathrm{~km}$ from north to south (Fig. 1), distributed in provinces of four Spanish administrative regions (number of deployed stations): (i) Catalonia: Girona (1), Barcelona (3), and Tarragona (1); (ii) the Valencian Community: Castellón (2), Valencia (6), Alicante (6); (iii) the Murcia Region: (2); and Andalusia: Almería (3). Table 1 shows a station inventory that includes names, georeferenced locations with their elevations, and operational time periods. The first station was set up in July 2003, and the last one in April 2011. All the stations continued to operate from the day they were set up until the end of 2012. Stations were placed at elevations ranging from 428 to $1319 \mathrm{~m}$ a.s.l., and at a maximum distance from the sea of $60 \mathrm{~km}$. To answer the question of whether collection gradients exist depending on elevation, some of the network's stations were arranged according to a relative geographic proximity but were placed at different elevations to make the best of the peculiarities of the relief.

Various statistics were calculated in order to perform a data analysis based on some compelling standards. Thus, the total rain and fog/pure fog collection rates for each station were calculated for all valid data. In any case, total and seasonal rates were calculated as the ratio between the collected volume of fog, pure fog or rain and the number of days the system operated in due form, for the whole study period in the case of total rates and for all of each season covered in this period in the case of seasonal rates.

As year 2011 was shared between all the operational time periods for all the sations and was also not affected by missing data, this was selected as the base period to perform comparative statistics between stations. Therefore, in Section 4.2, annual and seasonal percentages of days on which water was collected were calculated for year 2011 as the sum of the number of days when fog and/or rain is higher than zero, divided by the total number of days of the analysis period considered. This kind of analysis was performed to distinguish as a percentage when water came only from fog, from rain, or from both. With this intention, the stations that came into the analysis were chosen accordingly for the three typical lands covered by the network: the coast (Portella, Mondúver, and Arráez), the pre-littoral (Montseny Antenas and Crevillente) and the inland (Machos).

Revealing any statistical daily behavior of fog collection occurrence was the main objective in Section 4.3. For this, hourly statistical frequencies of the fog-water collection were calculated as the percentage of days for which any fog-water volume could be collected on a 24hourly basis. Again, the analysis period used was the 2011 year. Time duration in hours of fog collection episodes were also analysed, considering a fog-water collection episode as the event at which fog water could be collected non-stop at a time resolution of $1 \mathrm{~h}$, i.e. two episodes were considered distinct if a 1-hour period without any fog-water collection exists at least between them. Each of the fog collection episodes has its own associated collection rate which may be defined as the ratio of the entire fog water collected volume to the time length in hours.

Windrose evaluation, a statistical analysis of the most frequent wind

Table 1

Main characteristics of the fog-water collection stations used.

\begin{tabular}{|c|c|c|c|c|c|c|c|c|c|}
\hline Code & Station & Municipality & Province & Latitude & Longitude & Elevation (m a.s.l.) & Dist. to the sea $(\mathrm{km})$ & Start date & End date \\
\hline 1 & Puig Neulós & La Jonquera & Gerona & $42^{\circ} 28^{\prime} 51^{\prime \prime} \mathrm{N}$ & $02^{\circ} 56^{\prime} 47^{\prime \prime} \mathrm{E}$ & 1232 & 11 & $27 / 10 / 09$ & $31 / 12 / 12$ \\
\hline 2 & Montseny Antenas & Fogars de Montclús & Barcelona & $41^{\circ} 45^{\prime} 22^{\prime \prime} \mathrm{N}$ & $02^{\circ} 28^{\prime} 04^{\prime \prime} \mathrm{E}$ & 1230 & 21 & $17 / 06 / 10$ & $07 / 02 / 12$ \\
\hline 3 & Montseny Canplá & Fogars de Montclús & Barcelona & $41^{\circ} 44^{\prime} 39^{\prime \prime} \mathrm{N}$ & $02^{\circ} 27^{\prime} 23^{\prime \prime} \mathrm{E}$ & 832 & 21 & $17 / 06 / 10$ & $07 / 02 / 12$ \\
\hline 4 & Montnegre & Sant Cebrià de Vallalta & Barcelona & $41^{\circ} 39^{\prime} 36^{\prime \prime} \mathrm{N}$ & $02^{\circ} 35^{\prime} 47^{\prime \prime} \mathrm{E}$ & 648 & 7 & $18 / 06 / 10$ & $31 / 12 / 12$ \\
\hline 5 & Portella & Vandellòs i L'Hospitalet & Tarragona & $40^{\circ} 59^{\prime} 46^{\prime \prime} \mathrm{N}$ & $00^{\circ} 51^{\prime} 42^{\prime \prime} \mathrm{E}$ & 707 & 4 & 03/11/10 & $31 / 12 / 12$ \\
\hline 6 & Colomer & Cabanes & Castellón & $40^{\circ} 05^{\prime} 16^{\prime \prime} \mathrm{N}$ & $00^{\circ} 02^{\prime} 16^{\prime \prime} \mathrm{E}$ & 708 & 5 & $13 / 06 / 08$ & $31 / 12 / 12$ \\
\hline 7 & Casillas & Pina de Montalgrao & Castellón & $39^{\circ} 59^{\prime} 28^{\prime \prime} \mathrm{N}$ & $00^{\circ} 37^{\prime} 13^{\prime \prime} \mathrm{W}$ & 1150 & 46 & $23 / 03 / 04$ & $31 / 12 / 12$ \\
\hline 8 & Bujete & Cortes de Pallàs & Valencia & $39^{\circ} 15^{\prime} 10^{\prime \prime} \mathrm{N}$ & $00^{\circ} 53^{\prime} 57^{\prime \prime} \mathrm{W}$ & 780 & 52 & $07 / 04 / 11$ & $31 / 12 / 12$ \\
\hline 9 & Cinto Cabra & Cortes de Pallás & Valencia & $39^{\circ} 10^{\prime} 26^{\prime \prime} \mathrm{N}$ & $00^{\circ} 57^{\prime} 27^{\prime \prime} \mathrm{W}$ & 997 & 59 & $20 / 07 / 10$ & $31 / 12 / 12$ \\
\hline 10 & Machos Nieva & Ayora & Valencia & $39^{\circ} 00^{\prime} 53^{\prime \prime} \mathrm{N}$ & $00^{\circ} 53^{\prime} 40^{\prime \prime} \mathrm{W}$ & 1025 & 60 & $07 / 06 / 10$ & $31 / 12 / 12$ \\
\hline 11 & Machos & Ayora & Valencia & $39^{\circ} 00^{\prime} 52^{\prime \prime} \mathrm{N}$ & $00^{\circ} 53^{\prime} 39^{\prime \prime} \mathrm{W}$ & 1025 & 60 & $16 / 11 / 06$ & $31 / 12 / 12$ \\
\hline 12 & Machos LFC & Ayora & Valencia & $39^{\circ} 00^{\prime} 53^{\prime \prime} \mathrm{N}$ & $00^{\circ} 53^{\prime} 40^{\prime \prime} \mathrm{W}$ & 1025 & 60 & $15 / 03 / 07$ & $11 / 11 / 09$ \\
\hline 13 & Mondúver & Xeresa & Valencia & $39^{\circ} 00^{\prime} 37^{\prime \prime} \mathrm{N}$ & $00^{\circ} 15^{\prime} 55^{\prime \prime} \mathrm{W}$ & 843 & 8 & $16 / 07 / 03$ & $31 / 12 / 12$ \\
\hline 14 & Montgó & Denia & Alicante & $38^{\circ} 48^{\prime} 25^{\prime \prime} \mathrm{N}$ & $00^{\circ} 07^{\prime} 48^{\prime \prime} \mathrm{E}$ & 670 & 3 & $23 / 07 / 03$ & $31 / 12 / 12$ \\
\hline 15 & Mariola & Agres & Alicante & $38^{\circ} 46^{\prime} 09^{\prime \prime} \mathrm{N}$ & $00^{\circ} 30^{\prime} 22^{\prime \prime} \mathrm{W}$ & 1193 & 39 & $24 / 06 / 04$ & $31 / 12 / 12$ \\
\hline 16 & Bernia_E & Benissa & Alicante & $38^{\circ} 39^{\prime} 22^{\prime \prime} \mathrm{N}$ & $00^{\circ} 01^{\prime} 13^{\prime \prime} \mathrm{W}$ & 851 & 3 & $13 / 11 / 08$ & $31 / 12 / 12$ \\
\hline 17 & Puig Campana & Finestrat & Alicante & $38^{\circ} 35^{\prime} 50^{\prime \prime} \mathrm{N}$ & $00^{\circ} 11^{\prime} 48^{\prime \prime} \mathrm{W}$ & 1319 & 8 & $30 / 06 / 05$ & $09 / 02 / 07$ \\
\hline 18 & Sierra Helada & L'Alfàs del Pi & Alicante & $38^{\circ} 33^{\prime} 27^{\prime \prime} \mathrm{N}$ & $00^{\circ} 03^{\prime} 37^{\prime \prime} \mathrm{W}$ & 428 & 1 & $04 / 08 / 05$ & $31 / 12 / 12$ \\
\hline 19 & Crevillente & Crevillente & Alicante & $38^{\circ} 16^{\prime} 56^{\prime \prime} \mathrm{N}$ & $00^{\circ} 51^{\prime} 09^{\prime \prime} \mathrm{W}$ & 822 & 24 & $01 / 02 / 10$ & $31 / 12 / 12$ \\
\hline 20 & Muela_A & Cartagena & Murcia & $37^{\circ} 35^{\prime} 09^{\prime \prime} \mathrm{N}$ & $01^{\circ} 05^{\prime} 44^{\prime \prime} \mathrm{W}$ & 556 & 1 & $23 / 03 / 10$ & $16 / 05 / 12$ \\
\hline 21 & Muela_B & Cartagena & Murcia & $37^{\circ} 35^{\prime} 03^{\prime \prime} \mathrm{N}$ & $01^{\circ} 05^{\prime} 20^{\prime \prime} \mathrm{W}$ & 464 & 1 & $23 / 03 / 10$ & $16 / 05 / 12$ \\
\hline 22 & Arraez & Turre & Almería & $37^{\circ} 05^{\prime} 43^{\prime \prime} \mathrm{N}$ & $01^{\circ} 54^{\prime} 23^{\prime \prime} \mathrm{W}$ & 841 & 5 & $14 / 10 / 10$ & $31 / 12 / 12$ \\
\hline 23 & Alhamilla & Pechina & Almería & $36^{\circ} 59^{\prime} 03^{\prime \prime} \mathrm{N}$ & $02^{\circ} 22^{\prime} 27^{\prime \prime} \mathrm{W}$ & 1254 & 16 & $02 / 02 / 10$ & $31 / 12 / 12$ \\
\hline 24 & Peñones & Níjar & Almería & $36^{\circ} 50^{\prime} 01^{\prime \prime} \mathrm{N}$ & $02^{\circ} 04^{\prime} 52^{\prime \prime} \mathrm{W}$ & 487 & 3 & $08 / 07 / 10$ & $31 / 12 / 12$ \\
\hline
\end{tabular}


velocities and directions, and how it is related to the fog-water collection at a certain location is most recommended when designing a fogwater usage system (Estrela et al., 2009; Valiente et al., 2010). The main purpose of this evaluation, which is adressed in Section 4.4, is the correct orientation of flat LFCs towards the wind directions that bring the largest fog-water volumes, which optimises fog-water harvesting. The use of cylindrical collectors in combination with wind sensors allowed us to determine the optimal orientation for eventual LFCs at each of the network's stations.

Using all valid data at their maximum resolution available for the whole operational time period, i.e. wind directions and fog-water volumes at a 10-minute resolution, synthetic fog-water volumes were constructed for each of the stations by means of Eq. (1) (Estrela et al., 2009) for a set of 72 hypothetical LFC's orientations equally distributed from 0 to $360^{\circ}$, i.e. in $5^{\circ}$ intervals. From the set of synthetic fog-water volumes for each of the stations, the largest value is selected and its associated hypothetical LFC's orientation identified as the optimal orientation for which a maximum fog-water harvest may be obtained by means of flat collectors. The obtained optimal LFC orientation can be considered as an equivalent of the optimum mean wind direction the largest fog-water volumes could be harvested from.

$\varphi_{T}=\sum_{P} f_{i}\left|\cos \left(\theta p-\theta_{i}\right)\right|$

where:

$\theta_{i}$ is the 10-minute wind direction recorded by the station, expressed in degrees from North

$\theta_{p}$ is the LFC's orientation or angle sustained by a perpendicular axis to the LFC flat panel surface, expressed in degrees from North.

$f_{i}$ is the volume of fog water per square metre recorded by a cylindrical collector during a 10-minute period.

$P$ is the considered time period with data available for each station.

$\phi_{T}$ is the obtained synthetic fog-water volume per square metre for the time period considered.

\section{Results}

\subsection{Characterisation of the collected fog water volumes}

Table 2 provides the total (T) and seasonal (W, Sp, Sm and A) rain and fog/pure fog collection rates for all the network's stations per geographical sector. The mean total fog-water collection rate for all the network's stations was $3.91 / \mathrm{m}^{2} / \mathrm{d}$ (liter per square meter per day), with $1.6 \mathrm{~mm} / \mathrm{d}$ for precipitation. Among all the stations, the Puig Neulós stood out for its extraordinary fog-water collection rate, a $22.31 / \mathrm{m}^{2} / \mathrm{d}$ total rate for collected fog and a $18.81 / \mathrm{m}^{2} / \mathrm{d}$ total rate for pure-fog. The Puig Neulós station recorded its maximum monthly fog collection rate of $55.6 \mathrm{l} / \mathrm{m}^{2} / \mathrm{d}$ in March 2011, and its maximum annual rate of $24.2 \mathrm{l}$ / $\mathrm{m}^{2} / \mathrm{d}$ was recorded in 2010. The Montseny Antenas station also has a high fog collection total rate of $6.61 / \mathrm{m}^{2} / \mathrm{d}\left(6.2 \mathrm{l} / \mathrm{m}^{2} / \mathrm{d}\right.$ of total pure fog). This station was located $90 \mathrm{~km}$ from the Puig Neulós station, but at the same elevation as it. It is noteworthy that the Montseny Canplá station was only $900 \mathrm{~m}$ away from the Montseny Antenas station, but at a 400-m lower elevation, and that both operated during the same time period. However, the total fog rate obtained by the Montseny Canplá station was only $1.2 \mathrm{l} / \mathrm{m}^{2} / \mathrm{d}\left(0.81 / \mathrm{m}^{2} / \mathrm{d}\right.$ of total pure fog). This rate was 5 -fold lower than its neighbour station, which shows how important elevation is for fog-water collection.

It is worth noting the high fog collection values recorded by several stations located south of the province of Valencia and north of the province of Alicante; for instance, stations Montgó, Mariola and Bernia_E, with total fog rate values that come close to $61 / \mathrm{m}^{2} / \mathrm{d}$, or stations Portella and Mondúver, both at an elevation of 700 m.a.s.l. and a few kilometres from the coast, with total rates over $4 \mathrm{l} / \mathrm{m}^{2} / \mathrm{d}$. The fog collection rates recorded by several stations to the south of the study area were also noteworthy; e.g., the Arráez station whose recorded total rate exceeded $3.31 / \mathrm{m}^{2} / \mathrm{d}$.

Conversely, Montnegre station stood out for its low total fog collection rate, which was $0.51 / \mathrm{m}^{2} / \mathrm{d}\left(0.5 \mathrm{l} / \mathrm{m}^{2} / \mathrm{d}\right.$ of total pure fog). This station was located some $15 \mathrm{~km}$ from those located at the Montseny massif, at an elevation of 648 m.a.s.l., and closer to the sea. Likewise, stations Sierra Helada and Muela_B stood out as both were the most closely located ones to the sea of the whole network, $<1 \mathrm{~km}$, and also at the lowest elevation (428 m.a.s.l. and 464 m.a.s.l., respectively). During their operating period, their total fog collection rates were 1.0 and $1.1 \mathrm{l} / \mathrm{m}^{2} / \mathrm{d}$, respectively $\left(0.6\right.$ and $0.91 / \mathrm{m}^{2} / \mathrm{d}$ of total pure fog, respectively).

Regarding the seasonal regime of fog collection, we observed, as with precipitation, a marked annual cycle with two prominent collection periods, mainly in spring and autumn, and two less productive periods in winter and summer, where summer was the driest season. Puig Neulós station stood out for its high spring collection rate of $27.21 / \mathrm{m}^{2} / \mathrm{d}\left(19.3 \mathrm{l} / \mathrm{m}^{2} / \mathrm{d}\right.$ of spring pure fog), as did Montseny Antenas but for its autumn rate of $11.61 / \mathrm{m}^{2} / \mathrm{d}\left(10.51 / \mathrm{m}^{2} / \mathrm{d}\right.$ of autumn pure fog). Alhamilla and Montnegre stations were also noteworthy for their low summer fog collection rates with $0.11 / \mathrm{m}^{2} / \mathrm{d}\left(0.11 / \mathrm{m}^{2} / \mathrm{d}\right.$ of summer pure fog) for both cases.

The recorded rainfall values clearly showed a negative latitudinal gradient, with maximum values for the stations located north of the study area, and minimum ones to the south, except for those placed in south of Valencia and north of Alicante, a well-known area for its high rainfall. It is also worth noting how most rain rates were lower than those recorded for fog. Rain rates exceeded fog collection rates in only two of the studied stations (Montnegre and Montseny Canplá), being lower in all the other stations. Moreover, fog collection rates more than doubled the rain rates in most cases, with a ratio higher than 3:1 in several locations. This ratio between fog collection and rain rates considerably increased in summer, and in some places like Puig Neulós and Portella, it rose to $8: 1$ or to $4: 1$ at some southern locations to the study area, like Puig Campana or Peñones, or in Muela_A, whose ratio was $3: 1$.

\subsection{Annual and seasonal percentages of days with fog and/or rain}

Fig. 2 shows the annual and seasonal percentages of days for which fog-water and/or rain were collected for the year 2011. The graphical categories represent annual and seasonal percentages of the days with at least one event of "only fog", "fog and rain", "only rain" or "nothing collected". The category "fog and rain" included fog and rain events not necessarily concurrent but on the same day. By way of example, throughout 2011, water was collected on $27 \%$ of the days in winter by the Mondúver station (on $9 \%$ of the days, water came only from fog, from fog and rain on $>15 \%$, and from only rain for $>3 \%$ of the days), while no water of any kind was collected on $73 \%$ of the winter days.

In Fig. 2, we can see how the annual percentage of days when water was collected by stations varied among the different geographical sectors, and also among the different lands. The northern sector in its coastal location (Portella) had the highest percentage of days when fogwater was collected, either alone or with rain. In this sector, water was collected by coastal stations on $58 \%$ of the days, but the percentage descended acutely inland. In the central sector, water was collected on $45 \%$ of the days both on the coast and inland. In the southern sector, this value dropped to $35 \%$ in the two studied land locations.

When we looked at what happened for all four yearly seasons, we noticed different performances. Summer obtained the highest percentage of water collection days for the northern and central sectors, which was the case for most of the network's stations in these two sectors. Particularly, water was collected on $>50 \%$ of the days in the four analysed stations, and this figure rose to $75 \%$ of the days for Portella. One surprising outcome arose in summer which, despite presenting low collection rates than the other seasons, obtained the highest percentage of days with collection occurrence. Therefore, even though summer fog 
Table 2

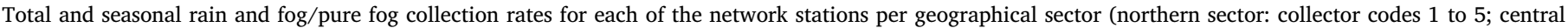

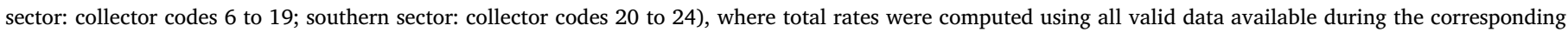
measurement period (T: Total; W: Winter; Sp: Spring; Sm: Summer; A: Autumn).

\begin{tabular}{|c|c|c|c|c|c|c|c|c|}
\hline \multirow[t]{4}{*}{ Code } & \multirow[t]{4}{*}{ Station } & Measurement period & \multirow[t]{4}{*}{ Variable } & \multirow[t]{4}{*}{$\mathrm{T}$} & \multirow[t]{4}{*}{$\mathrm{W}$} & \multirow[t]{4}{*}{$\mathrm{Sp}$} & \multirow[t]{4}{*}{$\mathrm{Sm}$} & \multirow[t]{4}{*}{ A } \\
\hline & & Start & & & & & & \\
\hline & & \multirow[b]{2}{*}{ (mm/yy) } & & & & & & \\
\hline & & & & & & & & \\
\hline 1 & Puig Neulós & $10 / 09$ & Rain $(\mathrm{mm} / \mathrm{d})$ & 3.3 & 1.4 & 3.3 & 1.9 & 6.2 \\
\hline & & $12 / 12$ & $\operatorname{Fog}\left(1 / \mathrm{m}^{2} / \mathrm{d}\right)$ & 22.3 & 22.8 & 27.2 & 16.8 & 22.3 \\
\hline & & & Pure fog $\left(1 / \mathrm{m}^{2} / \mathrm{d}\right)$ & 18.8 & - & 19.3 & 15.8 & 18.8 \\
\hline 2 & Montseny Antenas & $06 / 10$ & Rain $(\mathrm{mm} / \mathrm{d})$ & 2.3 & 0.7 & 4.0 & 1.9 & 3.4 \\
\hline & & $02 / 12$ & Fog $\left(1 / \mathrm{m}^{2} / \mathrm{d}\right)$ & 6.6 & 3.3 & 6.9 & 4.4 & 11.6 \\
\hline & & & Pure fog $\left(1 / \mathrm{m}^{2} / \mathrm{d}\right)$ & 6.2 & 3.3 & 6.7 & 4.1 & 10.5 \\
\hline 3 & Montseny Canplá & $06 / 10$ & Rain $(\mathrm{mm} / \mathrm{d})$ & 3.3 & 1.2 & 4.8 & 2.2 & 5.5 \\
\hline & & $02 / 12$ & $\operatorname{Fog}\left(1 / \mathrm{m}^{2} / \mathrm{d}\right)$ & 1.2 & 0.6 & 2.4 & 0.6 & 1.5 \\
\hline & & & Pure fog $\left(1 / \mathrm{m}^{2} / \mathrm{d}\right)$ & 0.8 & 0.5 & 1.6 & 0.3 & 0.9 \\
\hline 4 & Montnegre & $06 / 10$ & Rain $(\mathrm{mm} / \mathrm{d})$ & 2.8 & 1.0 & 3.4 & 1.4 & 5.0 \\
\hline & & $12 / 12$ & $\operatorname{Fog}\left(1 / \mathrm{m}^{2} / \mathrm{d}\right)$ & 0.5 & 0.3 & 1.0 & 0.1 & 0.8 \\
\hline & & & Pure fog $\left(1 / \mathrm{m}^{2} / \mathrm{d}\right)$ & 0.5 & 0.3 & 0.9 & 0.1 & 0.7 \\
\hline 5 & Portella & $11 / 10$ & Rain $(\mathrm{mm} / \mathrm{d})$ & 1.6 & 0.4 & 3.1 & 0.4 & 2.5 \\
\hline & & $12 / 12$ & $\operatorname{Fog}\left(1 / \mathrm{m}^{2} / \mathrm{d}\right)$ & 4.2 & 1.4 & 6.8 & 3.2 & 5.6 \\
\hline & & & Pure fog $\left(1 / \mathrm{m}^{2} / \mathrm{d}\right)$ & 3.9 & 1.4 & 5.9 & 3.1 & 4.7 \\
\hline 6 & Colomer & $06 / 08$ & Rain $(\mathrm{mm} / \mathrm{d})$ & 1.3 & 0.9 & 1.5 & 0.5 & 2.2 \\
\hline & & $12 / 12$ & Fog $\left(1 / \mathrm{m}^{2} / \mathrm{d}\right)$ & 3.3 & 3.0 & 4.5 & 1.3 & 4.7 \\
\hline & & & Pure fog $\left(1 / \mathrm{m}^{2} / \mathrm{d}\right)$ & 2.5 & 2.4 & 3.5 & 1.1 & 3.1 \\
\hline 7 & Casillas & $03 / 04$ & Rain $(\mathrm{mm} / \mathrm{d})$ & 1.4 & 0.7 & 2.0 & 0.8 & 2.1 \\
\hline & & $12 / 12$ & $\operatorname{Fog}\left(1 / \mathrm{m}^{2} / \mathrm{d}\right)$ & 2.1 & 1.8 & 2.7 & 1.0 & 3.1 \\
\hline & & & Pure fog $\left(1 / \mathrm{m}^{2} / \mathrm{d}\right)$ & 1.6 & 1.5 & 1.9 & 0.7 & 2.4 \\
\hline 8 & Bujete & $04 / 11$ & Rain $(\mathrm{mm} / \mathrm{d})$ & 1.4 & 0.6 & 1.8 & 0.4 & 2.6 \\
\hline & & $12 / 12$ & Fog $\left(1 / \mathrm{m}^{2} / \mathrm{d}\right)$ & 1.4 & 0.6 & 1.9 & 0.3 & 2.7 \\
\hline & & & Pure fog $\left(1 / \mathrm{m}^{2} / \mathrm{d}\right)$ & 1.0 & 0.4 & 1.2 & 0.2 & 2.0 \\
\hline 9 & Cinto Cabra & $07 / 10$ & Rain $(\mathrm{mm} / \mathrm{d})$ & 1.3 & 0.4 & 2.0 & 0.3 & 2.0 \\
\hline & & $12 / 12$ & $\operatorname{Fog}\left(1 / \mathrm{m}^{2} / \mathrm{d}\right)$ & 2.6 & 1.3 & 5.7 & 0.7 & 3.2 \\
\hline & & & Pure fog $\left(1 / \mathrm{m}^{2} / \mathrm{d}\right)$ & 2.2 & 1.3 & 4.8 & 0.6 & 2.2 \\
\hline 10 & Machos Nieva & $06 / 10$ & Rain $(\mathrm{mm} / \mathrm{d})$ & 1.4 & 0.6 & 1.9 & 0.7 & 2.4 \\
\hline & & $12 / 12$ & Fog $\left(1 / \mathrm{m}^{2} / \mathrm{d}\right)$ & 4.4 & 1.8 & 9.1 & 2.1 & 5.6 \\
\hline & & & Pure fog $\left(1 / \mathrm{m}^{2} / \mathrm{d}\right)$ & 4.0 & - & 8.6 & 1.9 & 4.7 \\
\hline 11 & Machos & $11 / 06$ & Rain (mm/d) & - & - & - & - & - \\
\hline & & $12 / 12$ & $\operatorname{Fog}\left(1 / \mathrm{m}^{2} / \mathrm{d}\right)$ & 3.4 & 2.0 & 4.3 & 2.2 & 5.2 \\
\hline & & & Pure fog $\left(1 / \mathrm{m}^{2} / \mathrm{d}\right)$ & 3.0 & 1.8 & 3.8 & 2.0 & 4.3 \\
\hline 13 & Mondúver & $07 / 03$ & Rain $(\mathrm{mm} / \mathrm{d})$ & 2.1 & 2.1 & 2.1 & 0.7 & 3.7 \\
\hline & & $12 / 12$ & Fog $\left(1 / \mathrm{m}^{2} / \mathrm{d}\right)$ & 4.5 & 5.0 & 5.9 & 1.7 & 5.5 \\
\hline & & & Pure fog $\left(1 / \mathrm{m}^{2} / \mathrm{d}\right)$ & 3.8 & 4.2 & 5.0 & 1.6 & 4.5 \\
\hline 14 & Montgó & $07 / 03$ & Rain $(\mathrm{mm} / \mathrm{d})$ & 2.7 & 3.3 & 2.8 & 0.9 & 3.8 \\
\hline & & $12 / 12$ & $\operatorname{Fog}\left(1 / \mathrm{m}^{2} / \mathrm{d}\right)$ & 5.8 & 6.0 & 7.5 & 3.5 & 6.6 \\
\hline & & & Pure fog $\left(1 / \mathrm{m}^{2} / \mathrm{d}\right)$ & 4.5 & 4.6 & 5.6 & 3.4 & 4.7 \\
\hline 15 & Mariola & $06 / 04$ & Rain (mm/d) & 1.5 & 1.4 & 1.5 & 0.4 & 2.6 \\
\hline & & $12 / 12$ & $\operatorname{Fog}\left(1 / \mathrm{m}^{2} / \mathrm{d}\right)$ & 5.7 & 7.5 & 6.2 & 2.0 & 7.3 \\
\hline & & & Pure fog $\left(1 / \mathrm{m}^{2} / \mathrm{d}\right)$ & 5.0 & 6.9 & 5.4 & 1.8 & 6.2 \\
\hline 16 & Bernia_E & $11 / 08$ & Rain $(\mathrm{mm} / \mathrm{d})$ & 1.6 & 1.5 & 1.5 & 0.7 & 2.7 \\
\hline & & $12 / 12$ & $\operatorname{Fog}\left(1 / \mathrm{m}^{2} / \mathrm{d}\right)$ & 6.0 & 6.0 & 8.0 & 2.3 & 7.7 \\
\hline & & & Pure fog $\left(1 / \mathrm{m}^{2} / \mathrm{d}\right)$ & 4.9 & 4.7 & 6.9 & 2.0 & 6.0 \\
\hline 17 & Puig Campana & $06 / 05$ & Rain $(\mathrm{mm} / \mathrm{d})$ & 1.2 & 1.9 & 1.3 & 0.2 & 1.5 \\
\hline & & $02 / 07$ & $\operatorname{Fog}\left(1 / \mathrm{m}^{2} / \mathrm{d}\right)$ & 3.6 & 5.9 & 3.9 & 0.9 & 3.8 \\
\hline & & & Pure fog $\left(1 / \mathrm{m}^{2} / \mathrm{d}\right)$ & 2.6 & - & 3.3 & 0.9 & 3.1 \\
\hline 18 & Sierra Helada & $08 / 05$ & Rain $(\mathrm{mm} / \mathrm{d})$ & 0.8 & 0.7 & 0.6 & 0.3 & 1.6 \\
\hline & & $12 / 12$ & Fog $\left(1 / \mathrm{m}^{2} / \mathrm{d}\right)$ & 1.0 & 1.0 & 0.8 & 0.2 & 1.7 \\
\hline & & & Pure fog $\left(1 / \mathrm{m}^{2} / \mathrm{d}\right)$ & 0.6 & 0.6 & 0.6 & 0.2 & 1.1 \\
\hline 19 & Crevillente & $02 / 10$ & Rain (mm/d) & 0.7 & 0.4 & 1.0 & 0.4 & 1.2 \\
\hline & & $12 / 12$ & Fog $\left(1 / \mathrm{m}^{2} / \mathrm{d}\right)$ & 1.7 & 1.4 & 2.2 & 0.8 & 2.3 \\
\hline & & & Pure fog $\left(1 / \mathrm{m}^{2} / \mathrm{d}\right)$ & 1.5 & 1.4 & 2.0 & 0.7 & 2.1 \\
\hline 20 & Muela_A & $03 / 10$ & Rain (mm/d) & 0.8 & 0.7 & 0.9 & 0.4 & 1.2 \\
\hline & & $05 / 12$ & Fog $\left(1 / \mathrm{m}^{2} / \mathrm{d}\right)$ & 2.0 & 1.4 & 3.1 & 1.2 & 1.8 \\
\hline & & & Pure fog $\left(1 / \mathrm{m}^{2} / \mathrm{d}\right)$ & 1.7 & 1.1 & 2.9 & 1.0 & 1.6 \\
\hline 21 & Muela_B & $03 / 10$ & Rain $(\mathrm{mm} / \mathrm{d})$ & 0.7 & 0.7 & 0.8 & 0.4 & 1.0 \\
\hline & & $05 / 12$ & Fog $\left(1 / \mathrm{m}^{2} / \mathrm{d}\right)$ & 1.1 & 0.8 & 1.8 & 0.5 & 1.1 \\
\hline & & & Pure fog $\left(1 / \mathrm{m}^{2} / \mathrm{d}\right)$ & 0.9 & 0.5 & 1.5 & 0.4 & 0.8 \\
\hline 22 & Arráez & $10 / 10$ & Rain $(\mathrm{mm} / \mathrm{d})$ & 1.4 & 0.9 & 1.5 & 0.3 & 2.7 \\
\hline & & $12 / 12$ & Fog $\left(1 / \mathrm{m}^{2} / \mathrm{d}\right)$ & 3.3 & 2.4 & 4.4 & 0.6 & 5.4 \\
\hline & & & Pure fog $\left(1 / \mathrm{m}^{2} / \mathrm{d}\right)$ & 2.5 & 2.0 & 2.2 & 0.6 & 4.7 \\
\hline 23 & Alhamilla & $02 / 10$ & Rain $(\mathrm{mm} / \mathrm{d})$ & 0.9 & 1.2 & 1.2 & 0.2 & 1.1 \\
\hline & & $12 / 12$ & Fog $\left(1 / \mathrm{m}^{2} / \mathrm{d}\right)$ & 1.9 & 2.2 & 3.5 & 0.1 & 2.0 \\
\hline & & & Pure fog $\left(1 / \mathrm{m}^{2} / \mathrm{d}\right)$ & 1.7 & 1.9 & 3.3 & 0.1 & 1.7 \\
\hline
\end{tabular}


Table 2 (continued)

\begin{tabular}{|c|c|c|c|c|c|c|c|c|}
\hline \multirow[t]{4}{*}{ Code } & \multirow[t]{4}{*}{ Station } & Measurement period & \multirow[t]{4}{*}{ Variable } & \multirow[t]{4}{*}{$\mathrm{T}$} & \multirow[t]{4}{*}{$\mathrm{W}$} & \multirow[t]{4}{*}{ Sp } & \multirow[t]{4}{*}{$\mathrm{Sm}$} & \multirow[t]{4}{*}{ A } \\
\hline & & Start & & & & & & \\
\hline & & End & & & & & & \\
\hline & & (mm/yy) & & & & & & \\
\hline \multirow[t]{3}{*}{24} & \multirow[t]{3}{*}{ Peñones } & $07 / 10$ & Rain $(\mathrm{mm} / \mathrm{d})$ & 0.7 & 0.8 & 0.7 & 0.1 & 1.2 \\
\hline & & $12 / 12$ & Fog $\left(1 / \mathrm{m}^{2} / \mathrm{d}\right)$ & 1.6 & 1.9 & 1.5 & 0.4 & 2.3 \\
\hline & & & Pure fog $\left(1 / \mathrm{m}^{2} / \mathrm{d}\right)$ & 1.3 & 1.5 & 1.2 & 0.4 & 1.9 \\
\hline
\end{tabular}

water collection is quite scarce, its presence is quite frequent. Winter gave the fewest days when water was collected throughout the territory, with collection percentages $<30 \%$ of all days. This result was also obtained for most of the network's stations.

The percentage of days on which water came exclusively from fog was also noteworthy, done to separate this meteorological phenomenon from rain, with which is it often associated on a daily basis. The percentage of days on which only fog-water was collected is represented in Fig. 2 by the horizontally striped area and appears at the bottom of each column. We observed that in 2011, summer was the season with the most days when this collection type took place in the majority of studied locations. However, in spring, the season with the highest
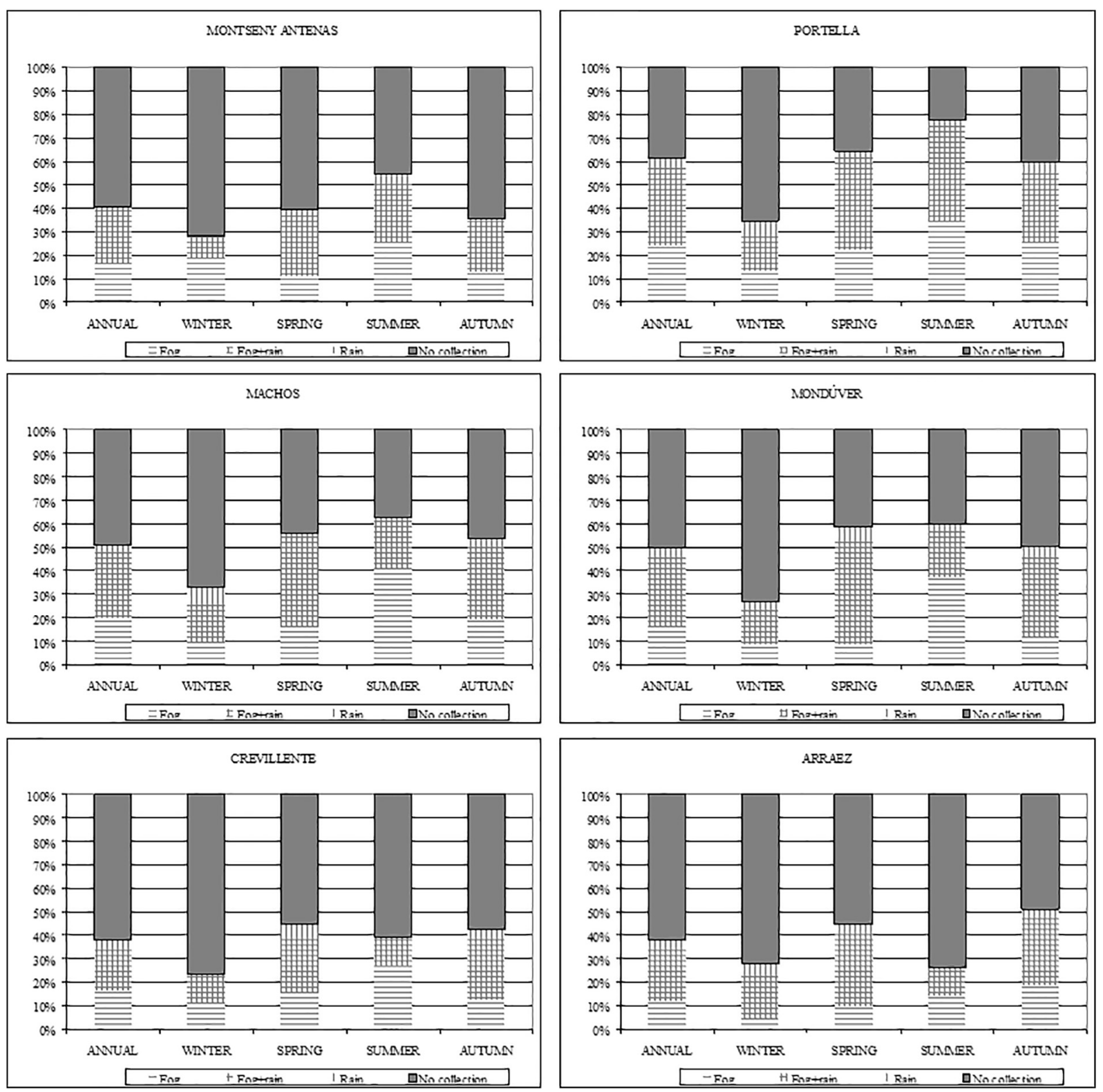

Fig. 2. 2011 annual and seasonal percentages of days with at least one event of "only fog", "fog and rain", "only rain" or "no collection", for the coastal stations of Portella, Mondúver and Arráez; the inland station of Machos and the pre-littoral stations of Montseny Antenas and Crevillente. 

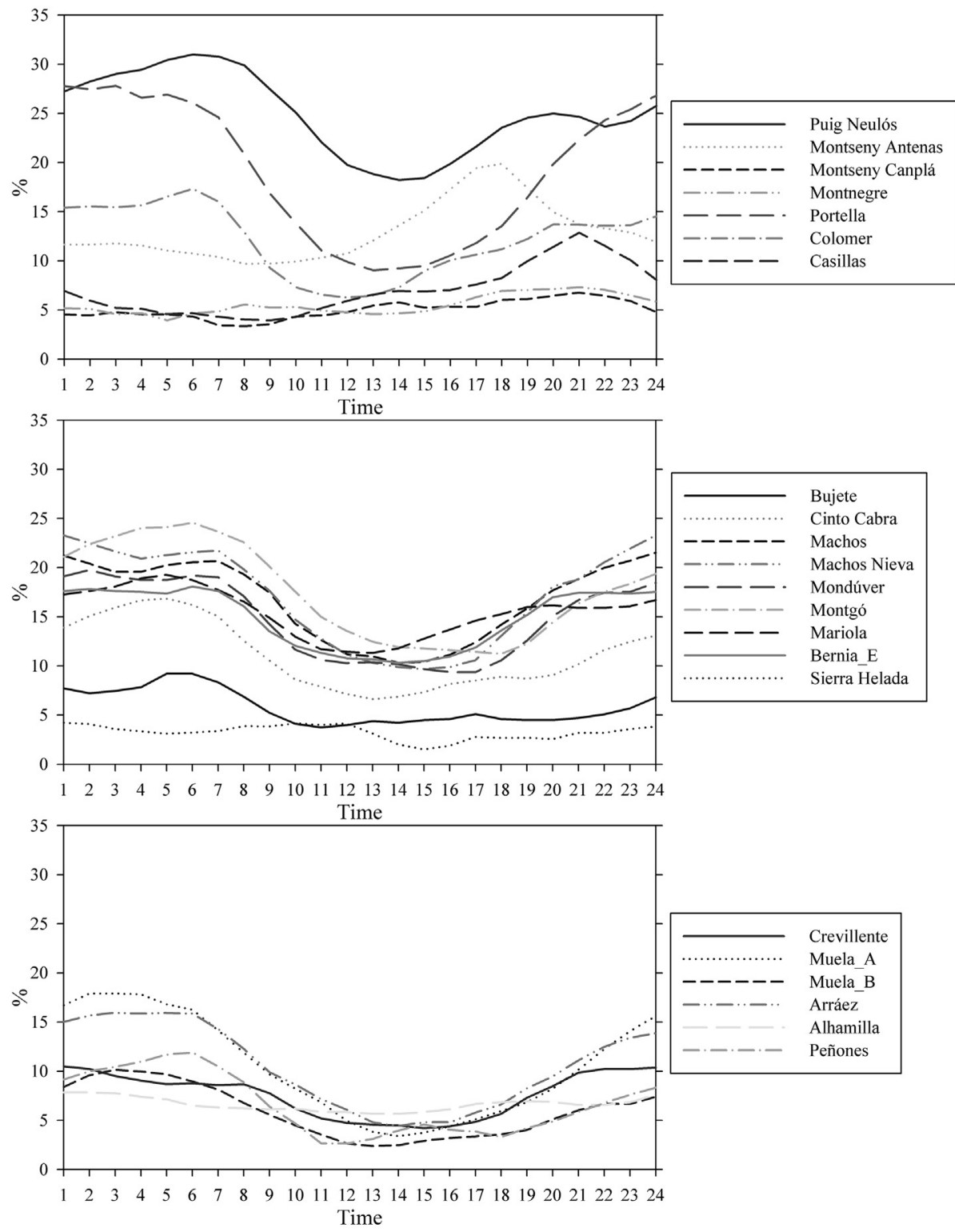

Fig. 3. Diurnal cycle of relative hourly frequencies of days with fog-water collection, using the whole 2011 data-period (northern sector at the upper plot, central sector at the middle plot, southern sector at the lower plot).

collection rates, the lowest frequencies of days with only fog were generally obtained. This result indicates that fog occurrence on these days tended to be associated with rain and cloud events. Conversely, the fact that summer obtained a high percentage of days when only fog was collected indicates that, despite summer being a climatologically dry season in precipitation terms, fog events are habitual as either advection or orographic, from which water can be drawn.

\subsection{Diurnal cycle of hourly frequencies and time length of fog-collection events}

Fig. 3 summarises the results on the daily variations of the hourly frequencies of fog-water collection for all the network's stations, grouped according to their geographical location. By way of example, with the Montgó station in 2011, fog was present (and water collected) at the 1-hour period centred at $06: 00 \mathrm{~h}$ on $25 \%$ of the days. A marked daily cycle can be seen for most locations, with higher frequencies at matutinal, vespertine and nocturnal hours, and lower frequencies for day-time hours.

The highest values of hourly frequency, above $30 \%$, were recorded first thing during the morning in the Puig Neulós station. The Portella station, also located in the northern sector, obtained similar frequencies to Puig Neulós station all night long, but the presence of fog diminished considerably during daytime hours. The lowest frequencies appeared in stations Montseny Canplá, Montnegre, and Sierra Helada, with a practically flat curve close to $5 \%$ for all diurnal hours, which slightly increased in the evening-nighttime. When we compared the three large sectors, we observed that the higher frequencies appeared in some stations in the northern sector. Nonetheless, this sector also contained some stations where fog was barely present, such as Montseny Canplá and Montnegre (Fig. 3). For some stations, like Montseny Antenas and Casillas, the maximum frequency appeared centred at 18:00 $\mathrm{h}$ and 21:00 h, respectively, rather than early in the morning as in most cases. The latter stations were set up at an elevation exceeding $1100 \mathrm{~m}$ a.s.l. and away from the sea $(21 \mathrm{~km}$ and $46 \mathrm{~km}$, respectively).

In the central sector, featuring only inland and coastal locations, we observed how stations displayed hourly frequencies commonly over 15\%; except for Bujete and, fundamentally Sierra Helada, where their hourly frequencies did not reach $5 \%$ for any one-hour period. In this way, the latter station had the least fog-water collection values of all the 

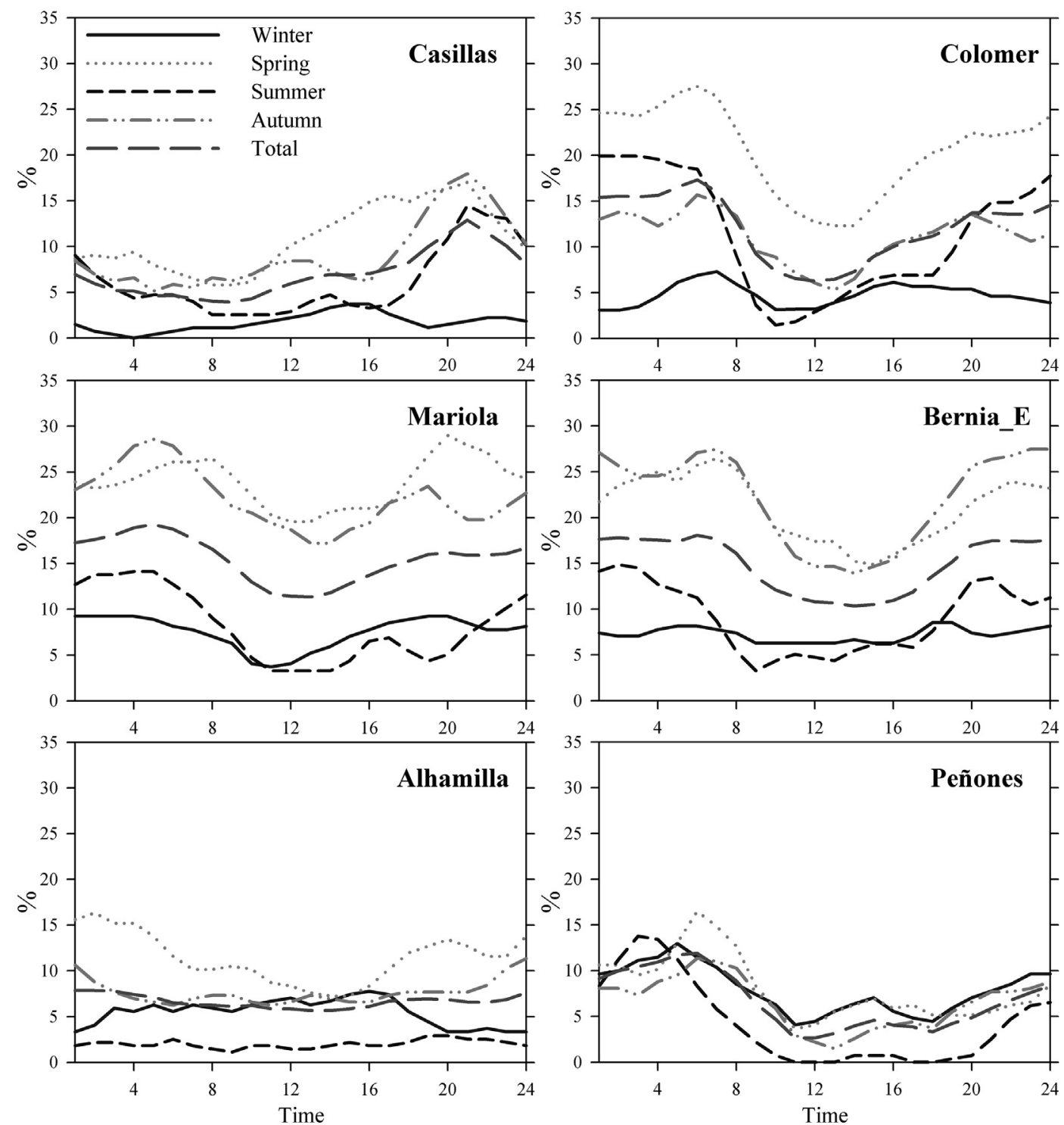

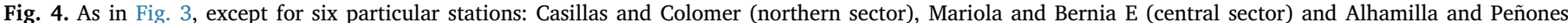
(southern sector); and for five 2011 analysed periods: the four seasons and the whole year.

analysed stations.

The stations belonging to the southern sector displayed a more consistent performance, resulting in a marked daily cycle for them all, with a maximum first thing in the early morning and a minimum at midday-early afternoon (Fig. 3). Fog occurrence was the highest in this sector at the Muela_A and Arráez stations, with a statistical frequency over $15 \%$ in the early morning, while the Alhamilla station obtained the lowest frequencies.

Daily cycles observed for the hourly frequencies of days with fogwater collection vary if different annual periods are considered into the analysis, i.e. seasonal periods versus the annual period. Fig. 4 shows these statistical frequencies for the four 2011 seasonal periods as compared to the annual period and for six particular stations distributed in the three sectors. By way of example, let's consider the following stations at the three different land locations: on the coast (Colomer, Bernia_E and Peñones), on the pre-littoral (Alhamilla) and inland (Casillas and Mariola). For the six stations, daily cycles are similar irrespective of the seasonal period, except for those with lower frequencies, when the curve was almost flat. Fog collection tends to occur at each station at certain time intervals, but with different statistical frequencies depending on the season. Spring obtained the highest percentage of days with fog occurrence in all the three sectors, and both inland and on the coast. In autumn, percentages were high and similar to those recorded for spring in the central sector but were less relevant in the other two sectors. However, the main differences among sectors went to the seasons with the least of fog occurrence. That is to say, winter in the northern sector obtained the lowest percentage of days with fog-water collection, but in the south, summer had a very low percentage in the stations furthest away from the coast (Alhamilla), and fog was virtually null at midday on the coast (Peñones) due most probably to heat and high solar radiation. In the central sector, no clear differences were found between winter and summer as fewer days were indicated for fog being collected for them both.

Fig. 5 depicts the time duration for each of the fog-water collection episodes registered for all the network's stations during 2011 as a function episode collection rate. Stations are distributed into the three geographical sectors already introduced as to make the interpretation of results easier. All in all, we found that the most frequent time durations of fog episodes lasted $<5 \mathrm{~h}$, but those lasting between 6 and $10 \mathrm{~h}$ were also abundant.

The time duration of the most frequent episodes is in line with the daily cycle obtained above for the hourly statistical frequencies. As 

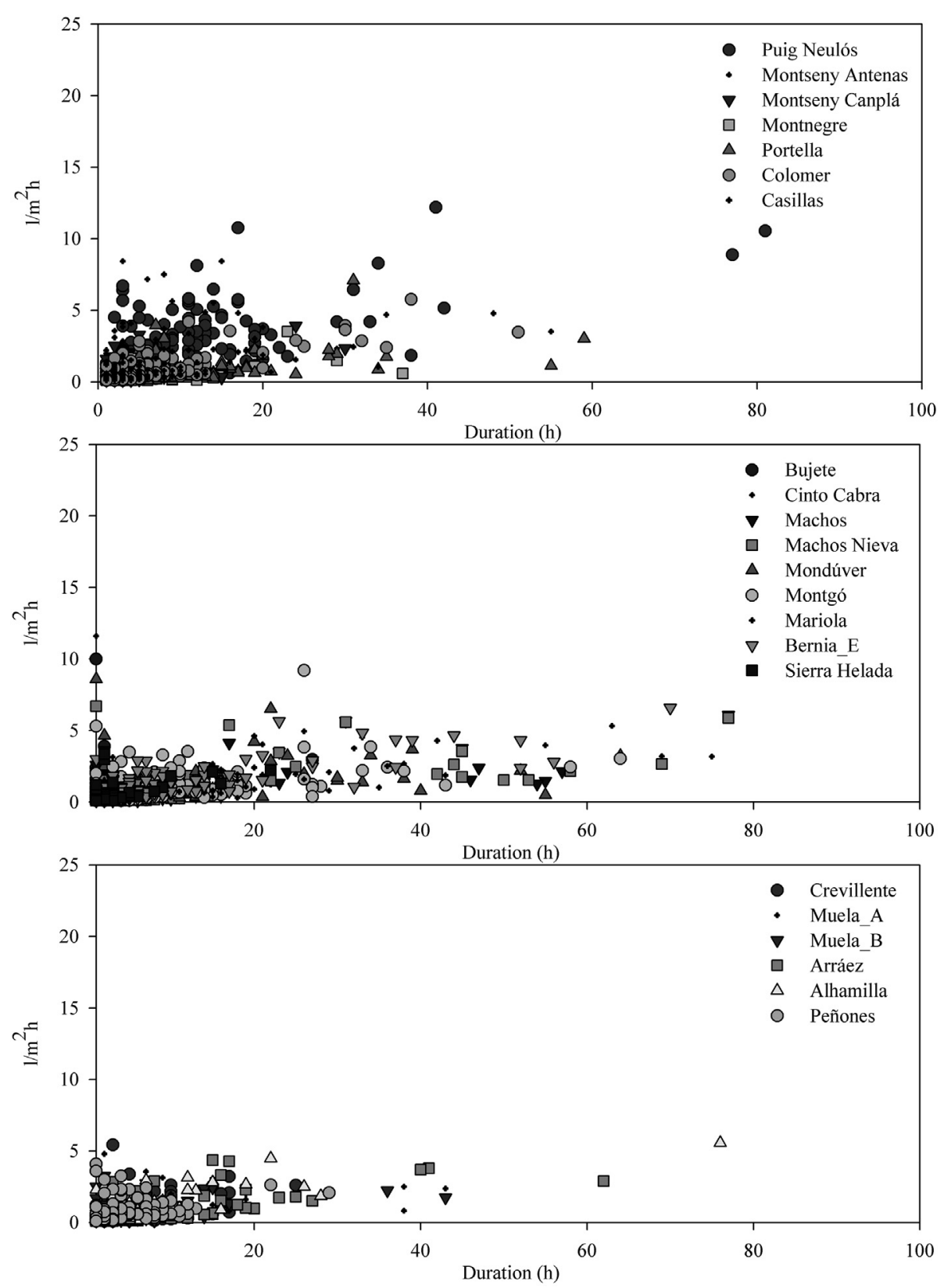

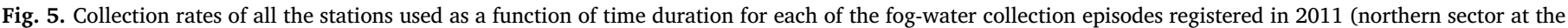
upper plot, central sector at the middle plot, southern sector at the lower plot).

mentioned above, the nocturnal hours obtained the highest fog-water collection frequencies, which is in accordance with the time duration of the most abundant episodes that do not tend to last longer than the nocturnal period. Puig Neulós station, however, may be considered an exception, with its outstanding high fog-water collection rates, although moderate for short episodes of $<10 \mathrm{~h}$ characterised with rates below $5 \mathrm{l} / \mathrm{m}^{2} / \mathrm{h}$. Note also that the resulting clusters of points in Fig. 5 roughly reveal that the higher the time duration of a fog episode, the larger the fog water collection rate will be.

The northern sector presented the episodes with the highest collection rates for the whole network, mainly by Puig Neulós and Montseny Antenas stations. Precisely, the highest collection rate was recorded in Puig Neulós station with a value of $12.21 / \mathrm{m}^{2} / \mathrm{h}$ for a 41 hour episode (from 13:00 h on 11 March to $05: 00 \mathrm{~h}$ on $13 \mathrm{March}$ ) and a maximum volume peak of $25.51 / \mathrm{m}^{2}$ during $1 \mathrm{~h}$. On the other hand, the longest lasting episode took also place in Puig Neulós and lasted $81 \mathrm{~h}$ (from 22:00 h on 13 March to $06: 00 \mathrm{~h}$ on $17 \mathrm{March}$ ), with a collection rate of $10.51 / \mathrm{m}^{2} / \mathrm{h}$. Apart from the extremes, time durations of the majority of episodes recorded in Puig Neulós station did not stand out for being longer than in other stations.

The central sector of the fog collection network is characterised by presenting a large number of episodes lasting $>20 \mathrm{~h}$ (Fig. 5). These episodes were recorded in stations both inland and on the coast, and no location, in particular, stood out. Conversely, Bujete and Sierra Helada stations are stressed for barely presenting long-lasting episodes, with their longest ones lasting 27 and $22 \mathrm{~h}$, respectively. The longest lasting episodes were recorded for Machos and Machos Nieva stations $(77 \mathrm{~h}$ between 22 and 25 March in both cases) and for Mariola ( $75 \mathrm{~h}$ between 7 and 10 March).

In the southern sector, fog collection episodes are characterised by their short duration, although many episodes lasting longer than $20 \mathrm{~h}$ were also recorded. Generally speaking, their collection rates were not much lower than in the other sectors, with only a few episodes exceeding $5 \mathrm{l} / \mathrm{m}^{2} / \mathrm{h}$. The longest lasting episode was also that for which 

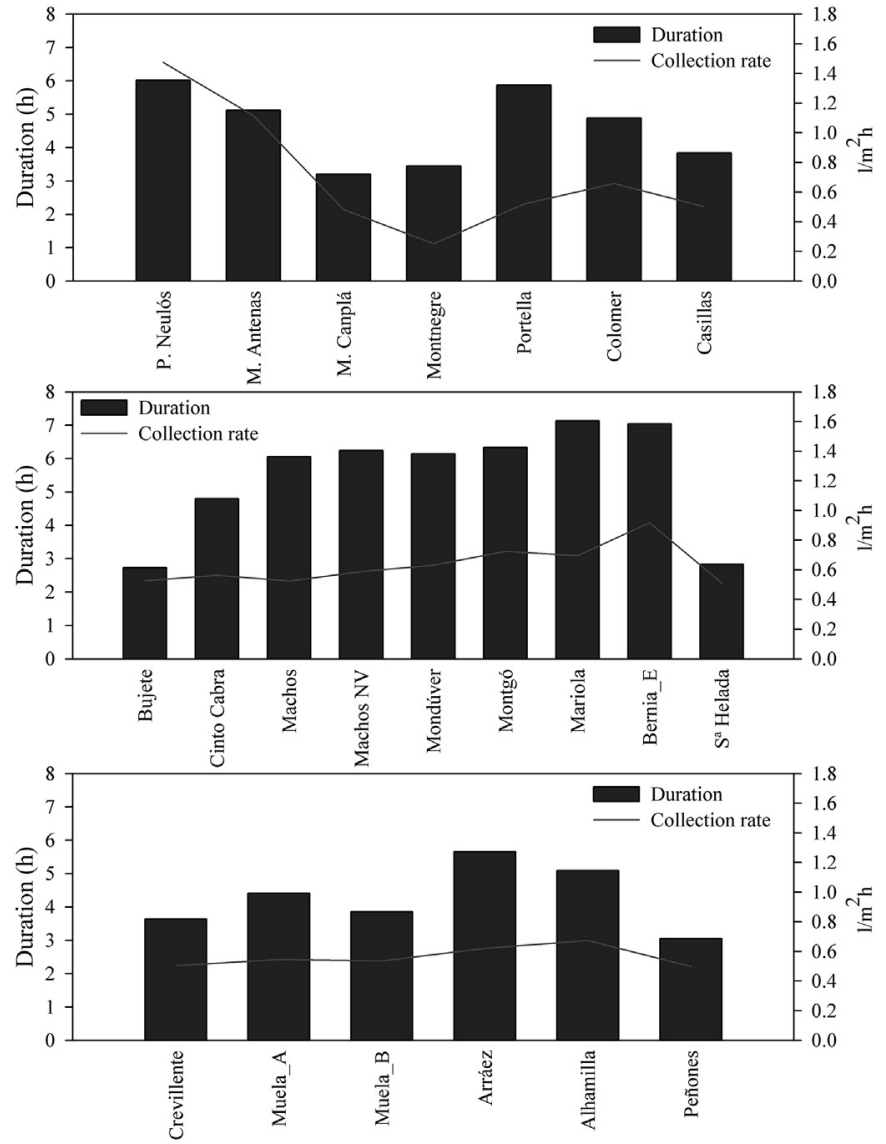

Fig. 6. For each network's station, averages of the time durations and collection rates corresponding to the fog-water collection episodes that took place in 2011 (northern sector at the upper plot, central sector at the middle plot, southern sector at the lower plot).

the highest average collection rate was recorded, which occurred in Alhamilla station and lasted $76 \mathrm{~h}$ (in March, from $08: 00 \mathrm{~h}$ on 8 March to 11:00 h on $11 \mathrm{March}$ ), with a collection rate of $5.61 / \mathrm{m}^{2} / \mathrm{h}$ and several volume peaks of $10 \mathrm{l} / \mathrm{m}^{2}$ in $1 \mathrm{~h}$ within the whole length of the episode.

In Fig. 6, the average of the time durations, as well as the average of the collection rates, are given for the 2011 combination of episodes for each of the stations. It is shown how the majority of the averages of episode collection rates ranges from 0.5 to $0.71 / \mathrm{m}^{2} / \mathrm{h}$ approximately, a quite narrow interval, except for Puig Neulós and Montseny Antenas stations where they take values above $11 / \mathrm{m}^{2} / \mathrm{h}$, Bernia_E station with $0.91 / \mathrm{m}^{2} / \mathrm{h}$ precisely and Montnegre station with the lowest average at $0.25 \mathrm{l} / \mathrm{m}^{2} / \mathrm{h}$. Averages of time durations, on the other hand, vary from $3 \mathrm{~h}$ up to $7 \mathrm{~h}$ without a clear pattern within geographical sectors.

Particularly, the northern sector housed the stations with the highest and lowest average collection rates of the network. The low collection rate for Montnegre station drew our attention, compared to the duration of its episodes and the rates of neighbouring stations. A particular comment is dedicated in the discussion section.

The central sector, specifically the part that lays between the South of the province of Valencia and the North of the province of Alicante, stood out as it presented stations on both the coast and inland with long average durations, which exceeded $7 \mathrm{~h}$ at Mariola and Bernia_E. The average duration of Machos, Machos Nieva, Mondúver and Montgó stations lasted longer than $6 \mathrm{~h}$, still a notable value if compared to other stations outside the central sector.

For the southern sector, Arráez and Alhamilla stations presented the longest durations on average, reaching a 5-h value; whereas Peñones station obtained in average the lowest durations with a 3-hour mean. The results of Muela_A and Muela_B stations were striking as they were separated from one another by only $600 \mathrm{~m}$ but at different elevations. In both cases, the average collection rate was similar, but their episode durations differed. Muela_A was set up at a higher elevation, with longer fog episodes, which meant that the total collected water volumes were higher than at the neighbouring Muela_B.

\subsection{Optimum mean wind directions for fog-water harvesting}

Fig. 7 shows the obtained optimal orientations for eventual LFCs to harvest fog-water efficiently at each of the network's stations according to the use of Eq. (1). Table 3 contains these optimal orientations as well as the synthetic fog-water volumes, averaged over the length of one year, which would be harvested at each location by properly oriented LFCs. We can see how neighbouring stations can present different optimal orientations. This is the case of the pair of stations formed by Montseny Antenas (2) and Montseny Canplá (3), or of the group comprising Montgó (14), Bernia_E (16), Puig Campana (17) and Sierra Helada (18).

Table 3 uses all the available data at each of the stations to provide the optimal LFC orientation. Nevertheless, available data may be grouped by seasonal period and optimal orientations recalculated for each of these periods (Fig. 8). Mainly, it is shown how optimal LFC orientations did not widely vary among seasons in most cases, except for some few stations like Sierra Helada, Bujete or Alhamilla. In particular, the fog-water collection rate for Sierra Helada was small given its low geographic elevation, which meant that there was no dominant wind direction to carry fog to this location. For the other two of the few cases, a longer time period is necessary than that employed to do the calculations and to determine if the observed seasonal variations of optimal orientation are important or not. An optimal LFC orientation exists for all the other stations, albeit a few nuances and minor differences among seasons.

\section{Discussion}

The analysis done allowed us to know the fog-water collection potential at the 23 locations that are distributed throughout the Mediterranean Iberian Peninsula. Our results proved relevant for prospecting the fog-water collection potential, mainly in terms of collected volumes, the most productive seasonal periods of the year, day-long collection occurrence, the time duration of episodes with fog collection occurrence, and the optimal harvesting direction at each of the stations. This last outcome denotes the usefulness of conducting a wind rose evaluation and its relation to the fog-water collection before setting up an industrial fog-water collection system in order to optimise harvesting.

A widespread daily cycle was observed in the statiscal analysis of the hourly frequencies of fog-water collection, probably due to orographic fogs forming and dissipating since they could be linked to the air-temperature diurnal cycle. When temperature lowers, the water vapour present in the rising mass of air becomes easier to condense and form fog. Conversely, when air temperature increases during the day, the rising air would make it more difficult for water vapour to condense, which would inhibit fog from forming.

Low collection rates for the fog collection episodes present at Montnegre station may be explained because a particular bias for this site. The abundant vegetation that surrounded the spot where the station was located may have been interfering with the measurements. It was hard finding a clearance to set up a station, and the surrounding area had to be selectively cleared to improve the sampling conditions there. Even though attempts were made to set up the equipment in a spot where trees did not act as a barrier, perhaps performing more intense clearing would have been necessary to collect water under better conditions. This is why the data for this station must be cautiously included in all the analyses.

Reaching conclusions about the latitudinal or longitudinal 


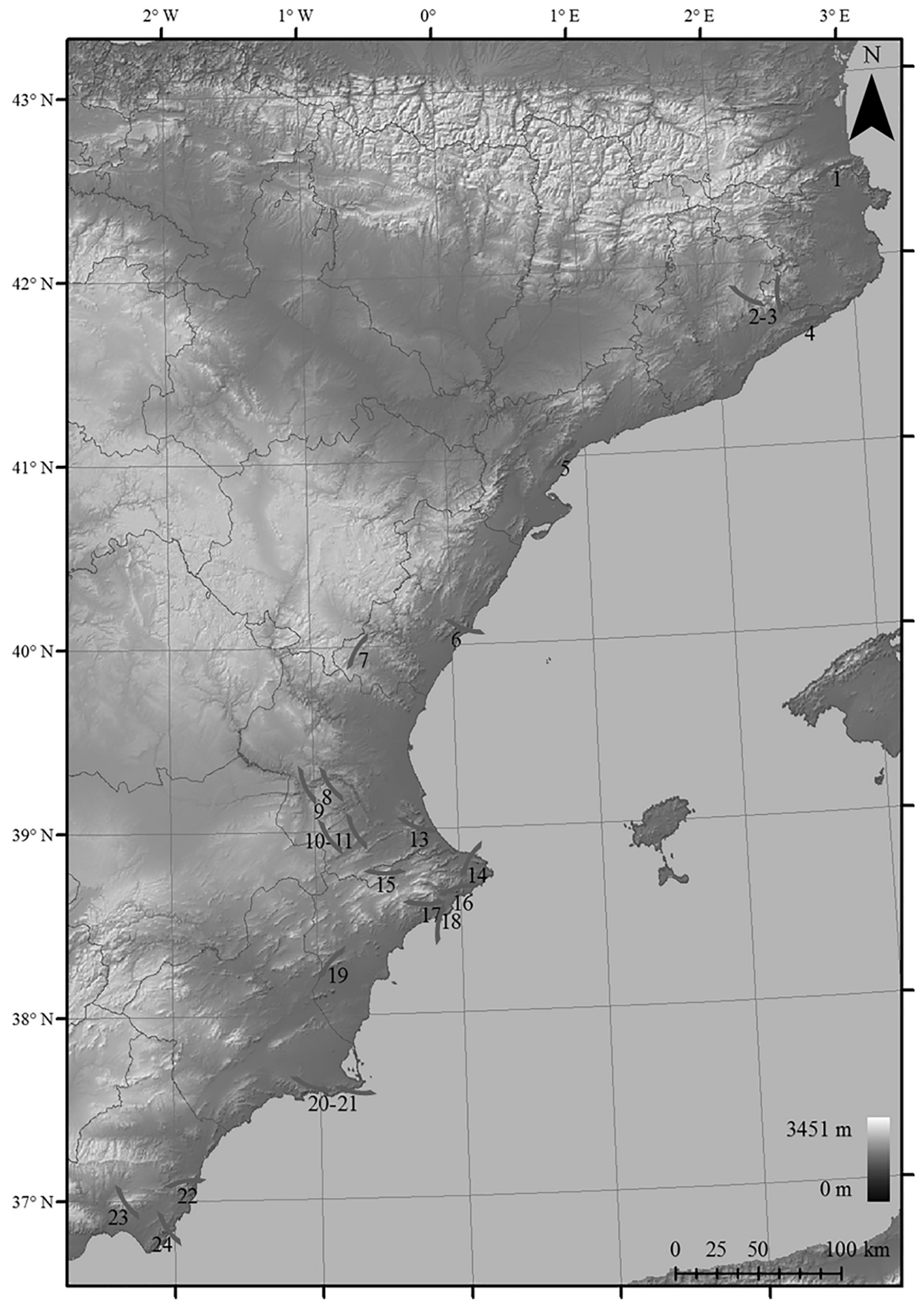

Fig. 7. Optimal orientations for eventual LFC implementations in fog harvesting prospective activities. Arched lines represent LFCs oriented towards the main fogwater collection directions, while figures indicate the respective station-code numbers. 
Table 3

Largest synthetic fog-water collection volumes averaged over a one-year period and associated LFC's orientations for an optimal implementation in eventual fog-water prospecting activities. Data used in the analysis correspond to the time period from July 2003 to December 2012.

\begin{tabular}{|c|c|c|c|c|}
\hline \multirow[t]{2}{*}{ Code } & \multirow[t]{2}{*}{ Station } & $\begin{array}{l}\text { Time period: } \\
\text { Stard-End }\end{array}$ & \multirow[t]{2}{*}{$\begin{array}{l}\text { Optimal LFC's } \\
\text { orientation }\left({ }^{\circ} \mathrm{N}\right)\end{array}$} & \multirow[t]{2}{*}{$\begin{array}{l}\text { Synthetic annual } \\
\text { volume average (1/ } \\
\left.\mathrm{m}^{2}\right)\end{array}$} \\
\hline & & (mm/yy) & & \\
\hline 1 & Puig Neulós & $10 / 09-12 / 12$ & 155 & 6983 \\
\hline 2 & $\begin{array}{l}\text { Montseny } \\
\text { Antenas }\end{array}$ & $06 / 10-02 / 12$ & 30 & 2144 \\
\hline 3 & $\begin{array}{l}\text { Montseny } \\
\text { Canplá }\end{array}$ & $06 / 10-02 / 12$ & 85 & 373 \\
\hline 4 & Montnegre & $06 / 10-12 / 12$ & 170 & 153 \\
\hline 5 & Portella & $11 / 10-12 / 12$ & 135 & 1459 \\
\hline 6 & Colomer & $06 / 08-12 / 12$ & 20 & 1151 \\
\hline 7 & Casillas & 03/04-12/12 & 120 & 635 \\
\hline 8 & Bujete & $04 / 11-12 / 12$ & 55 & 449 \\
\hline 9 & Cinto Cabra & $07 / 10-12 / 12$ & 65 & 899 \\
\hline 10 & Machos Nieva & $06 / 10-12 / 12$ & 55 & 1518 \\
\hline 11 & Machos & $11 / 06-12 / 12$ & 60 & 1144 \\
\hline 13 & Mondúver & $07 / 03-12 / 12$ & 20 & 1304 \\
\hline 14 & Montgó & $07 / 03-12 / 12$ & 120 & 1613 \\
\hline 15 & Mariola & $06 / 04-12 / 12$ & 0 & 1625 \\
\hline 16 & Bernia_E & $11 / 08-12 / 12$ & 165 & 1864 \\
\hline 17 & Puig Campana & 06/05-02/07 & 0 & 1116 \\
\hline 18 & Sierra Helada & $08 / 05-12 / 12$ & 100 & 238 \\
\hline 19 & Crevillente & $02 / 10-12 / 12$ & 130 & 531 \\
\hline 20 & Muela_A & $03 / 10-05 / 12$ & 20 & 703 \\
\hline 21 & Muela_B & $03 / 10-05 / 12$ & 10 & 383 \\
\hline 22 & Arraez & $10 / 10-12 / 12$ & 170 & 980 \\
\hline 23 & Alhamilla & $02 / 10-12 / 12$ & 55 & 585 \\
\hline 24 & Peñones & $07 / 10-12 / 12$ & 55 & 545 \\
\hline
\end{tabular}

distribution of fog collection is difficult as other factors, like elevation, mountain aspect or surrounding relief, can prove crucial during collection. Throughout the whole analysed latitudinal profile, we observed locations with high fog-water collection rates in areas close to the coastline, and also inland. Puig Neulós station stood out from all the rest for its extremely high and comparable average collection rates to those obtained in countries like Peru (Ortega et al., 2007; Villegas et al., 2007) or the Sultanate of Oman (Cereceda and Schemenauer, 1998), two places with two of the highest collection values described in the literature. The rest of stations feature collection average rates not as high as in Puig Neulós station, but still being significant in some cases.

In coastal stations like Arráez, Bernia_E, Mondúver, Montgó, and Portella, or in other mountainous stations that lay further away from the coast like Mariola, Machos or Montseny Antenas, where the distance to the sea could sometimes be as much as $60 \mathrm{~km}$, considerable volumes of fog-water were obtained. Nevertheless, slight average collection rates were also recorded in most land locations such as some coastal stations (Montnegre, Muela_B and Sierra Helada) or other inland (Bujete and Montseny Canplá).

This work reveals the key role played by elevation in the fog-water collection. A minimum elevation is necessary to effectively collect fogwater. Besides, differences in elevation of the order of $100 \mathrm{~m}$ can lead to considerable variations in collected volumes. In line with this, we found that an elevation above $500 \mathrm{~m}$ a.s.l.was necessary to obtain sufficient collection rates in the central and southern sectors of our study area. This minimum elevation seems to increase in the northern sector where slight collection rates were recorded at elevations between $600 \mathrm{~m}$ and $850 \mathrm{~m}$, particularly for stations in the provinces of Barcelona and Girona, and it was only at elevations over $1200 \mathrm{~m}$ a.s.l. where high collection rates were obtained (Corell et al., 2014a). In addition to the dependence on elevation, it is worth mentioning that the collected volumes widely varied, depending on the season of the year. The least productive seasonal period attending to collected volumes was summer, followed by winter, being spring and autumn the most productive seasons by this order all over the study area (Corell et al., 2014b).

Another important aspect to stress is a usual presence of fog during the summer period. A major feature in Mediterranean climates is an important depletion of rainfall during the summer periods causing droughts and dry conditions. Similar depletion was also observed for fog-water collection rates during summer at most of the stations, however, this drop was less marked than the one associated to the precipitation rate. Despite the lower collection rates in summer than during the other seasons, it was possible to collect fog-water more frequently in the summer period, even without the presence of rainfall episodes. This must be partly due to the short time that fog lasts in summer in our study region, because typical high summer temperatures easily disperse fog during the day time. The barometric swamp that dominates the Iberian Peninsula during the summer period favours the formation of local circulations in the form of breezes which lead to low cloud formation in this part of the Mediterranean basin (Azorin-Molina et al., 2011). These clouds, which anchor to the peaks of Mediterranean mountain accidents, do not tend to result in rain but fog when it comes into contact with coastal mountains (Azorin-Molina et al., 2009, 2010). Such cloudiness preferentially forms in the evening and continues until the next morning to dissipate during the hours when solar radiation peaks. At some of the network stations, where there was practically no summer precipitation, we observed that the collected fog-water to rain ratio increased in the summer months. This was indeed the case of Peñones and Puig Campana stations, where this ratio was 4 to 1 in favour of fog. Therefore, we believe that this a good, yet unknown, alternative source of water not used by humans to date in our area that may help to carry out activities in forests, such as repopulations or pools to help fight forest fires.

\section{Conclusion}

This study has presented both a methodology for the analysis of fogwater collection measurements and the outcomes from a network of fog-water monitoring stations. Being passive and omnidirectional the used cylindrical fog sensors, wind is a key element that takes part as a transport mechanism for the advection of fog droplets. This is especially favourable in interface areas where the cloudy circulation and terrestrial elevations in the form of mountains intersect, locations that were precisely selected for the deployment of the network stations.

When the installation of passive fog-water collectors is sought in order to have greater probabilities for the collection of water, one important recommendation is the selection of geographical elevations between 500 and $1500 \mathrm{~m}$ above sea level. Moreover, if the choice is for an inland, the difference in height from the valley bottom should be at least $300 \mathrm{~m}$, appearing as a large step in the orography. A remarkable conclusion of the present study is that the larger the elevation, even under $100 \mathrm{~m}$ differences, the greater fog-water collection potential, as demonstrated by Muela_A and _B stations. Additionally, distance in a straight line to the coast should be as small as possible. The ideal locations would be in the range of $20 \mathrm{~km}$ from the sea, although distances $>80 \mathrm{~km}$ may also offer good possibilities of collection levels.

Typically, summer is the season with the least fog-water volumes. However, it is the period when fog episodes are most frequent. The depletion in the fog-water collection during the summer season is not as high as the decrease in rainfall, making the ratio between fog collection and rain rates even larger in summer than during the rest of year. Statistically, fog episodes are present more frequently at matutinal, vespertine and/or nocturnal hours, with a clear depletion during the midday which is more common in the summer season.

When fog-water volumes and measured wind data are combined to obtain optimum mean wind directions for fog-water harvesting by LFCs, valuable outcomes are gathered for eventual fog water usage activities. Therefore, main optimal LFC orientations for inland locations should be in line with the direction of the valley to which they belong and in the shortest direction to the coastline, being their collected fog- 


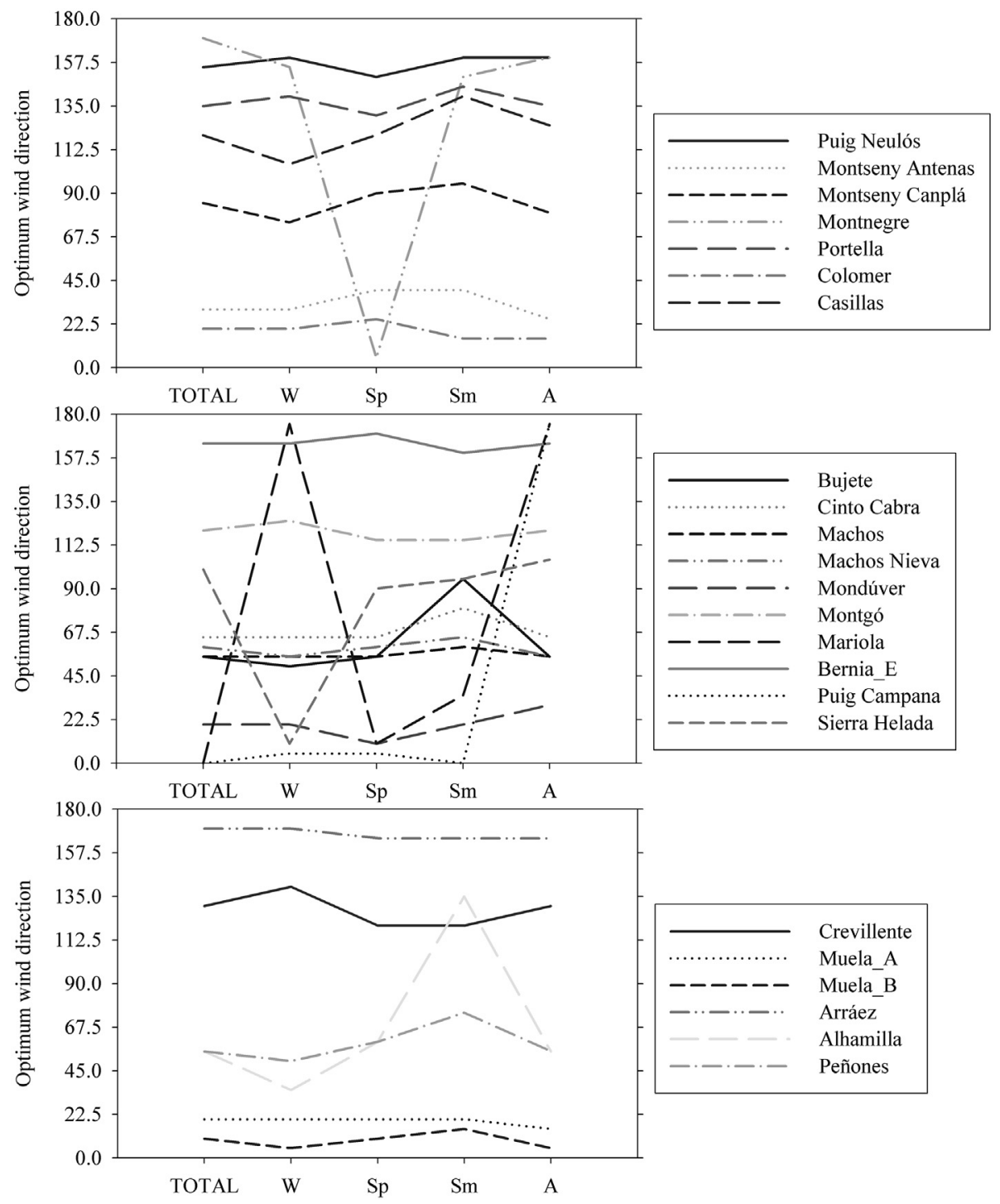

Fig. 8. Eventual optimal LFC orientations as a result of considering different time periods in eq. 1: autumn (A), summer (Sm), spring (Sp), winter (W) and all available data (TOTAL), for each of the network stations and associated operative time span from July 2003 to December 2012 (northern sector at the upper plot, central sector at the middle plot, southern sector at the lower plot).

water volumes generally smaller than those near the coast. On the other hand, LFCs at littoral locations would present more dispersed optimal orientations, ranging from north to the direction of the most immediate coastline. Collected volumes are generally larger than those registered inland. An important characteristic is the practically null dependence of the optimal orientations regarding seasonality. On the opposite, captured volumes would depend greatly on seasonality.

\section{Aknowledgments}

This study has been funded by the Spanish Ministerio de Economía y Competitividad and the European Regional Development Fund (FEDER) through the project CGL2015-64268-R (MINECO/FEDER, UE). The Fundación CEAM is partly supported by Generalitat Valenciana and research projects "DESESTRES" PROMETEOII/2014/038 (Consellería de Cultura) and "VERSUS" CGL2015-67466-R (Spanish Ministry of Science and Technology).

\section{References}

Azorin-Molina, C., Sanchez-Lorenzo, A., Calbo, J., 2009. A climatological study of sea breeze clouds in the Southeast of the Iberian Peninsula (Alicante, Spain). Atmósfera
22 (1), 33-49.

Azorin-Molina, C., Corell, D., Estrela, M.J., Valiente, J.A., 2010. Fog water collection under sea breeze conditions in the western Mediterranean basin (Valencia region, Spain). In: Proceeding of 5th International Conference on Fog, Fog Collection and Dew 25-30 Julio 2010. University of Münster, Münster (Alemania), pp. 65-68.

Azorin-Molina, C., Tijm, S., Chen, D., Baldi, M., 2011. A multi-year study of sea breezes in a Mediterranean coastal site: Alicante (Spain). Int. J. Climatol. 31 (3), 468-486.

Capel-Molina, J., 2000. El clima de la Península Ibérica. Editorial Ariel, colección Ariel Geografía, Barcelona.

Cereceda, P., Schemenauer, R.S., 1998. Fogwater collection at El Tofo, Chile and other coastal sites in South America and Arabia. In: Schemenauer, R.S., Bridgman, H. (Eds.), Proceedings of the First International Conference on Fog and Fog Collection. Vancouver, Canada. July 19-24, 1998. International Development Research Centre (IDRC), Ottawa, Canada, pp. 409-411 Edited by.

Corell, D., Estrela, M.J., Valiente, J.A., 2011. Obtenció d'aigua a partir de la boira en el Montnegre y en d'altres indrets del litoral Mediterrani. La revista del Montnegre y del Corredor 11 (11), 21-25 L'Aulet, número. noviembre 2011.

Corell, D., Estrela, M.J., Valiente, J.A., Azorín, C., Martín-Vide, J., Chen, D., 2014a. Análisis sinóptico de los días con recolección de agua de niebla en el nordeste de la Península Ibérica. In: Fernández-Montes, S., y Rodrigo, F.S. (Eds.), Cambio Climático y Cambio Global. Publicaciones de la Asociación Española de Climatología (AEC), Almería Serie A.

Corell, D., Estrela, M.J., Valiente, J.A., Barceló, S., Capel, J.J., 2014b. Captación del agua de niebla en determinados enclaves del Sudeste de la Península Ibérica. In: Fernández-Montes, S., Rodrigo, F.S. (Eds.), Cambio Climático y Cambio Global. Publicaciones de la Asociación Española de Climatología (AEC), 2014, Almería Serie A.

Cuadrat, J.M., Martin Vide, J., 2007. La Climatología Española. PASADO, Presente y 
Futuro. Prensas Universitarias de Zaragoza, Zaragoza.

De Castro, M., Martín Vide, J., Alonso, S., 2005. El clima de España: pasado, presente y escenarios de clima para el siglo XXI. In: Moreno Rodríguez, J.M.C. (Ed.), Evaluación Preliminar de los Impactos en España por Efecto del Cambio Climático. Ministerio de Medio Ambiente y Universidad de Castilla-La Mancha, pp. 1-64.

De Luis, M., Brunetti, M., Gonzalez-Hidalgo, J.C., Longares, L.A., Martín-Vide, J., 2010. Changes in seasonal precipitation in the Iberian Peninsula during 1946-2005. Glob. Planet. Chang. 74 (1), 27-33.

Estrela, M.J., Peñarrocha, D., Millán, M., 2000. Multi-annual drought episodes in the Mediterranean (Valencia region) from 1950-1996. A Spatio-temporal analysis. Int. J. Climatol. 20, 1599-1618.

Estrela, M.J., Valiente, J.A., Corell, D., Millán, M., 2008. Fog collection in the western Mediterranean basin (Valencia region, Spain). Atmos. Res. 87, 324-337.

Estrela, M.J., Valiente, J.A., Corell, D., Fuentes, D., Valdecantos, D., 2009. Prospective use of collected fog water in the restoration of degraded burned areas under dry Mediterranean conditions. Agric. For. Meteorol. 149, 1896-1906.

Estrela, T., Ṕerez-Martin, M.A., Vargas, E., 2012. Impacts of climate change on water resources in Spain. Hydrol. Sci. J. 57, 1154-1167.

Falconer, R.E., Falconer, P.D., 1980. Determination of cloud water acidity at a mountain observatory in the Adirondack Mountains of New-York State. J. Geophys. Res.Oceans Atmos. 85 (NC12), 7465-7470.

Gallart, F., Llorens, P., 2002. Water resources and environmental change in Spain. A key issue for sustainable catchment management. In: García Ruiz, J.M., Jones, J.A.A., y Arnaez, J. (Eds.), Environmental Change and Water Sustainability. IPE-CSIC Zaragoza, pp. 11-20.

García Ruiz, J.M., López Moreno, J.I., Vicente Serrano, S., Lasanta Martínez, T., Beguería, S., 2011. Mediterranean water resources in a global change scenario. Earth-Sci. Rev. 105, 121-139.

Gil Olcina, A., Rico, A., 2007. El Problema del Agua en la Comunidad Valenciana. Fundación Agua y Progreso de la Comunidad Valenciana. Generalitat Valenciana.

Instituto Tecnológico y Geominero de España y Consellería de Agricultura y Medio Ambiente, 1996. Los Recursos Hídricos en la Comunidad Valenciana, Madrid.

Juvik, J.O., Nullet, D., 1995. A proposed standard fog collector for use in high-elevation regions. Comment. J. Appl. Meteorol. 34 (9), 2108-2110.

Klemm, O., Schemenauer, R., Lummerich, A., Cereceda, P., Marzol, V., Corell, D., Van Heerden, J., Reinhard, D., Gherezghiher, T., Olivier, J., Osses, P., Sarsour, J., Frost, E., Estrela, M.J., Valiente, J.A., Mussie, F., 2012. Fog as a Fresh-Water Resource: Overview and Perspectives. Ambio 41 (3), 221-234.

Martin Vide, J., López-Bustins, J.A., 2006. The Western Mediterranean Oscillation and rainfall in the Iberian Peninsula. Int. J. Climatol. 26 (11), 1455-1475.

Martín-Vide, J., Olcina-Cantos, J., 2001. Climas y tiempos de España. Alianza Editorial, S.A, Madrid.

Millán, M., Estrela, M.J., Vallejo, R., 1998. Evaluation of the hidrological inputs in the Mediterranean basin. In: Schemenauer y, R.S., Bridgman, H. (Eds.), In Proceedings of the First International Conference on Fog and Fog Collection. Vancouver, Canada. July 19-24, 1998. International Development Research Centre (IDRC), Ottawa, Canada, pp. 281-284.

Millán, M., Estrela, M.J., Sanz, M.J., Mantilla, E., Martin, M., Pastor, F., Salvador, R., Vallejo, R., Alonso, L., Gangoiti, G., Ilardia, J.L., Navazo, M., 2005a. Climatic feedbacks and desertification: the Mediterranean Model. J. Clim. 18, 684-701.

Millán, M., Estrela, M.J., Miró, J., 2005b. Rainfall components: variability and spatial distribution in a mediterranean area (Valencia region). J. Clim. 18, 2682-2705.

Ministerio de Medio Ambiente, 1998. Libro Blanco del Agua en España. Secretaría de
Estado y Aguas del Ministerio de Medio Ambiente, Madrid.

Ministerio de Medio Ambiente, 2000a. Plan Hidrológico Nacional: Análisis de antecedentes y transferencias planteadas, (Documento policopiado), Madrid.

Ministerio de Medio Ambiente, 2000b. Plan Hidrológico Nacional: Análisis de los Sistemas Hidráulicos, (Documento policopiado), Madrid.

Miró, J.J., Estrela, M.J., Caselles, V., Olcina, J., 2016. Fine-scale estimations of bioclimatic change in the Valencia region, Spain. Atmos. Res. 180, 150-164.

Miró, J.J., Caselles, V., Estrela, M.J., 2017. Multiple imputation of rainfall missing data in the Iberian Mediterranean context. Atmos. Res. 197, 313-330. Holanda. https://doi. org/10.1016/j.atmosres.2017.07.016.

Olivier, J., De Rautenbach, C.J., 2002. The implementation of fog water collection systems in South Africa. Atmos. Res. 64 (1-4), 227-238.

Ortega, A., Talavera, C., Jiménez, P., Villegas, L., 2007. The use of fog water in the ecosystems restoration in arid zones: Lomas of Atiquipa. In: Biggs, A., Cereceda, P. (Eds.), Proceedings of the Fourth International Conference on Fog, Fog Collection and Dew. Atacama Desert Center. Pontificia Universidad Católica de Chile, pp. 241-244.

Pérez Cueva, A.J., 2001. Las sequías en tierras Valencianas. In: Causas y consecuencias de las sequías en España. Instituto Universitario de Geografía, Universidad de Alicante, Caja de Ahorros del Mediterráneo, pp. 131-159.

Quereda Sala, J., Montón Chiva, E., Escrig, J., 1999. Las tendencias climáticas de la región mediterránea ¿cambio o estabilidad? Rev. valencia. d'estudis autonòmics 27 , 117-152 (Ejemplar dedicado a: Innovación, tecnología, logística y empresa en la Comunidad Valenciana).

Schemenauer, R.S., Cereceda, P., 1994. A proposed standard fog collection for use in high elevations regions. J. Appl. Meteorol. 33 (11), 1313-1322.

Schemenauer, R.S., Banic, C.M., Urquizo, N., 1995. High elevation fog and precipitation chemistry in southern Quebec, Canada. Atmos. Environ. 29 (17), 2235-2252.

Tejedor, E., De Luis, M., Cuadrat, J.M., Esper, J., Saz, M.Á., 2016. Tree-ring-based drought reconstruction in the Iberian Range (east of Spain) since 1694. Int. J. Climatol. 60, 361-372.

Tejedor, E., Saz, M.A., Cuadrat, J.M., Esper, J., De Luis, M., 2017. Temperature variability of the Iberian Range since 1602 inferred from tree-ring records. Clim. Past Discuss. 13, 93-105.

Valiente, J.A., Estrela, M.J., Corell, D., Fuentes, D., Valdecantos, A., 2010. Fog water collection and reforestation on mountain locations in a western Mediterranean basin region. In: Proceeding of 5th International Conference on Fog, Fog Collection and Dew 25-30 Julio 2010. vol. 2010. University of Münster, Münster (Alemania), pp. $52-55$.

Valiente, J.A., Estrela, M.J., Corell, D., Fuentes, D., Valdecantos, A., 2011. Fog water collection and reforestation at a mountain location in a western Mediterranean basin region: air-mass origins and synoptic analysis. Erdkunde 65, 277-290 (FI. 0.452, C. Geography Physical 33 (34), Geography 37 (72).

Vicente-Serrano, S., Lopez-Moreno, J.I., Beguería, S., Lorenzo-Lacruz, J., SanchezLorenzo, A., García-Ruiz, J.M., Azorin-Molina, C., Morán-Tejeda, E., Revuelto, J., Trigo, R., Coelho, F., Espejo, F., 2014. Evidence of increasing drought severity caused by temperature rise in southern Europe. Environ. Res. Lett. 9 (4), 1-9. https://doi. org/10.1088/1748-9326/9/4/044001. num.

Villegas, L., Jiménez, P., Talavera, C., Ortega, A., 2007. Evaluation of fog water catchment in Atiquipa Lomas (Arequipa-Peru) from 2002 to 2006. In: Biggs, A., Cereceda, P. (Eds.), Proceedings of the Fourth International Conference on Fog, Fog Collection and Dew. Atacama Desert Center. Pontificia Universidad Católica de Chile, pp. $225-227$. 